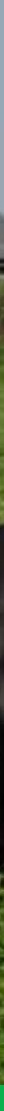

\title{
Gross margin insurance on Dutch dairy and fattening pig farms
}

Marcel van Asseldonk and Miranda Meuwissen 



\section{Gross margin insurance on Dutch dairy and fattening pig farms}

Marcel van Asseldonk and Miranda Meuwissen 
Van Asseldonk, M., and M. Meuwissen, 2017. Gross margin insurance on Dutch dairy and fattening pig farms. Wageningen, Wageningen Economic Research, Report 2017-026. 32 pp.; 17 fig.; 8 tab.; 25 ref.

Fluctuations of input and output prices are major reasons causing volatile gross margins in Dutch livestock production. By means of time-series analysis the potential impact of livestock gross margin insurance instruments is studied. Depending on the coverage level, gross margin insurance could provide Dutch farmers protection against the loss of gross margin. For example in the dairy sector, simulating a farm-specific coverage level threshold of $€ 0.25$ per kg milk would reduce volatility by $17 \%$ (of the median of the coefficient of variation value). In the fattening pig sector, simulating for example a farm-specific coverage level threshold of $€ 50$ per pig would reduce volatility by $30 \%$ (of the median of the coefficient of variation value). Furthermore, national-based triggers are less effective than farm-specific triggers in smoothening gross margin, because of heterogeneous gross margins between farms.

Key words: insurance, gross margin, agriculture, FADN

This report can be downloaded for free at http://dx.doi.org/10.18174/416977 or at www. wur. eu/economic-research (under Wageningen Economic Research publications).

(C) 2017 Wageningen Economic Research

P.O. Box 29703, 2502 LS The Hague, The Netherlands, T +31 (0)7033583 30,

E communications.ssg@wur.nl, http://www.wur.eu/economic-research. Wageningen Economic Research is part of Wageningen University \& Research.

\section{(cc) BY-NC}

For its reports, Wageningen Economic Research utilises a Creative Commons Attributions 3.0 Netherlands license.

(C) Wageningen Economic Research, part of Stichting Wageningen Research, 2017

The user may reproduce, distribute and share this work and make derivative works from it. Material by third parties which is used in the work and which are subject to intellectual property rights may not be used without prior permission from the relevant third party. The user must attribute the work by stating the name indicated by the author or licensor but may not do this in such a way as to create the impression that the author/licensor endorses the use of the work or the work of the user. The user may not use the work for commercial purposes.

Wageningen Economic Research accepts no liability for any damage resulting from the use of the results of this study or the application of the advice contained in it.

Wageningen Economic Research is ISO 9001:2008 certified.

Wageningen Economic Research Report 2017-026 | Project code 2282300191

Cover photo: Shutterstock 


\section{Contents}

$\begin{array}{ll}\text { Preface } & 5\end{array}$

$\begin{array}{ll}\text { Summary } & 6\end{array}$

$\begin{array}{lll}\text { S.1 Key findings } & 6\end{array}$

$\begin{array}{lll}\text { S.2 Complementary results } & 7\end{array}$

$\begin{array}{lll}\text { S.3 Method } & 7\end{array}$

$\begin{array}{llr}1 & \text { Introduction } & 9\end{array}$

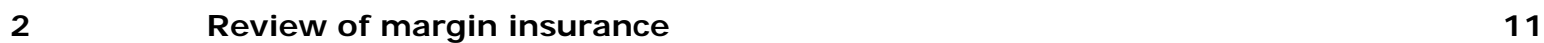

2.1 The concept 11

$\begin{array}{lll}2.2 & \text { Role of public sector } & 12\end{array}$

$\begin{array}{lll}2.3 & \text { Experience } & 13\end{array}$

2.4 Typical example $\quad 16$

3

$\begin{array}{ll}\text { Potential impact of margin insurance in the Netherlands } & 18\end{array}$

$\begin{array}{lll}3.1 & \text { Data analysis } & 18\end{array}$

3.2 Gross margin volatility 19

3.2.1 Dairy sector $\quad 19$

$\begin{array}{ll}3.2 .2 \text { Fattening pig sector } & 21\end{array}$

3.3 Potential impact gross margin insurance $\quad 23$

$\begin{array}{ll}\text { 3.3.1 Dairy sector } & 23\end{array}$

$\begin{array}{ll}\text { 3.3.2 Fattening pig sector } & 24\end{array}$

4 Conclusions and outlook $\quad 26$

4.1 Potential impact of gross margin insurance $\quad 26$

$\begin{array}{lll}4.2 & \text { Potential role of gross margin insurance } & 27\end{array}$

$\begin{array}{lll}4.3 & \text { Outlook gross margin insurance and CAP } & 28\end{array}$

$\begin{array}{ll}\text { References and websites } & 29\end{array}$

$\begin{array}{lll}\text { Appendix } 1 & \text { Family farm income volatility } & 31\end{array}$ 



\section{Preface}

This report provides an analysis of income volatility and the potential protection against the loss of gross margin by means of insurance in Dutch agriculture. This topic is of increasing interest for farmers as well as for policy makers.

The question on how to contribute best to farm income stability (and level) has always been a fundamental question within the CAP. It has gained renewed attention due to budgetary constraints in light of other emerging political priorities and - more recently - persisting pressure on agricultural markets. An income stabilisation tool marks the CAP's first foray into the domain of income insurance, following the features of US agricultural policy to facilitate insurance against fluctuating market prices. Besides uptake of revenue based insurance schemes in the US, also gross margin insurance schemes are gaining momentum. Livestock gross margin insurance policies provide protection against the loss of gross margin, i.e. output value minus variable costs. As such, gross margin insurance provides protection when input costs rise or output prices drop.

We express our thanks to the Dutch Ministry of Economic affairs for its financial support, and in particular we thank Karel van Bommel, Elselien Breman and Henk Riphagen for their valuable comments.

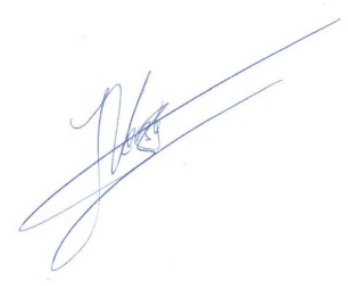

Prof.dr.ir. J.G.A.J . (J ack) van der Vorst General Director Social Sciences Group (SSG)

Wageningen University \& Research 


\section{Summary}

\section{S.1 Key findings}

Large differences in gross margin volatility between dairy and fattening pigs Fluctuations of input and output prices are major reasons causing volatile gross margins in livestock production. There are large historic differences in the period 2001-2015 between the dairy sector and fattening pig sector in volatility. Relatively large fluctuations in gross margins were observed in the fattening pig sector (median coefficient of variation (CV) value of $32 \%$ ). In the dairy sector gross margin between years was more smooth (median CV values of $12 \%$ ), but projections are that after the gradual reduction of EU milk price support and following the abolishment of the EU milk quota system dairy farmers will become more exposed to the world market for dairy products and are becoming more vulnerable to (supply and demand) shocks affecting world dairy markets and prices.

Gross margin insurance reduces volatility by up to $30 \%$

Depending on coverage level, gross margin insurance could provide protection against the loss of gross margin (see Figure S.1). For example in the dairy sector, simulating a farm-specific coverage level threshold of $€ 0.25$ per $\mathrm{kg}$ milk would imply an average pay-out (and risk premium) of approximately $€ 2,500$ per year per farm and would reduce volatility by $17 \%$ (of the median value). In the fattening sector, simulating for example a farm-specific coverage level threshold of $€ 50$ per pig would imply an average pay-out (and risk premium) of approximately $€ 7,500$ per year per farm and would reduce volatility by $30 \%$ (of the median value). Furthermore, national-based triggers are less effective in smoothening gross margin, because of heterogeneous gross margins between farms.

Data-intensive design

Designing farm-specific gross margin insurance is data intensive as data are required on sales prices, input prices, and quantities (i.e., inputs and production). Moreover, moral hazard problems may occur as production volumes from intensive livestock systems are largely determined by farm management decisions and timing of sales is somewhat flexible. Using national-based data and triggers can circumvent data intensity and moral hazard issues but is found to be less effective.

Two potential roles

With regard to the role of the public sector, two potential roles have been identified. Governments can financially intervene in gross margin insurance as a response to market failure with regard to covering correlated risks (e.g. prices and yields). Alternatively, they could provide incentives for price transparency, including collection and dissemination of information on price levels and price drivers, such as (local and international) storage levels. 


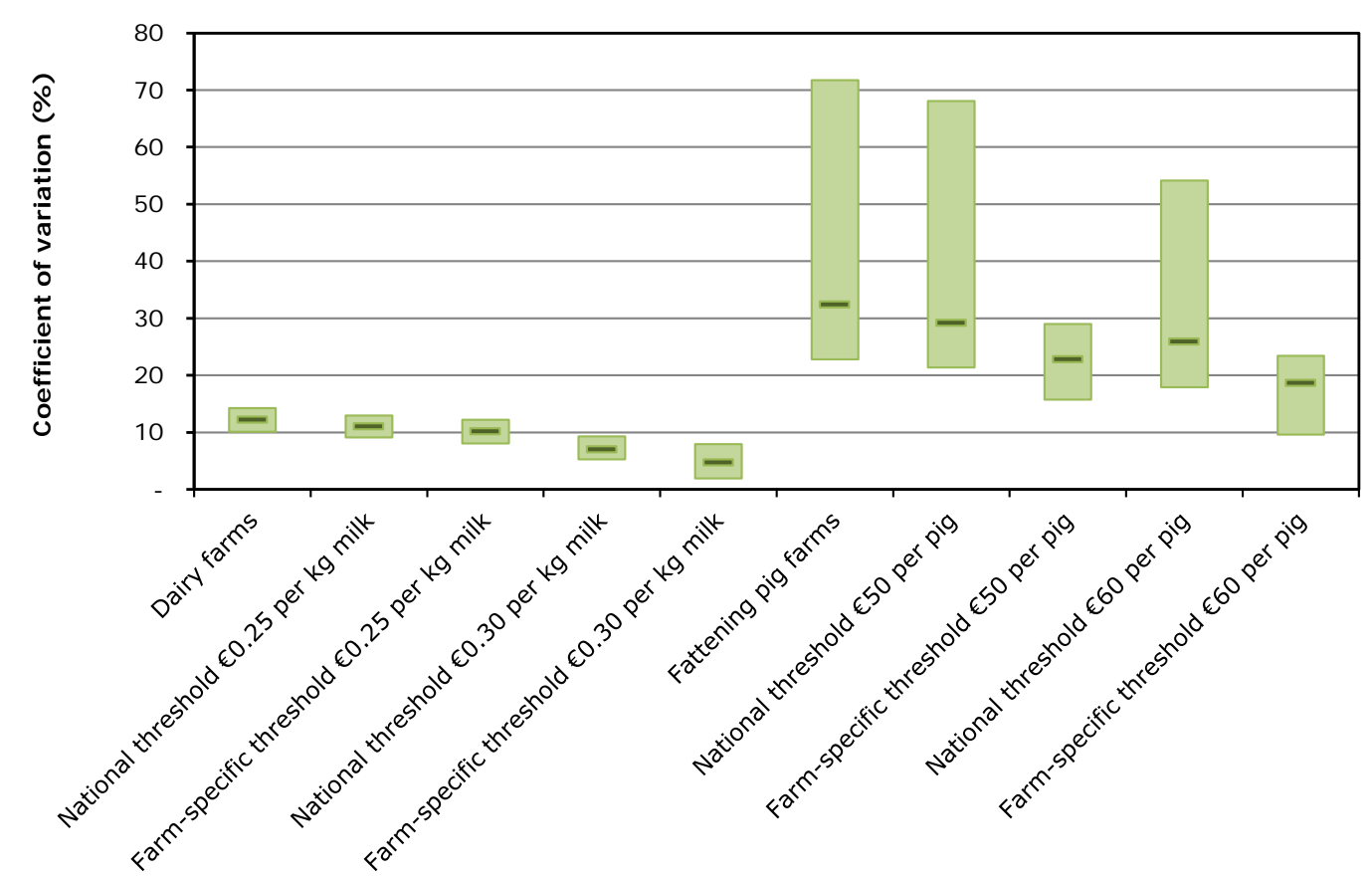

Figure S.1 Coefficient of variation of gross margin $^{1}$ (median, 20 percentile value and 80 percentile value) on Dutch dairy and fattening pig farms without or with alternative forms of gross margin insurance (national versus farm-specific triggers and pay-outs)

${ }^{1}$ Milk revenue minus compound feed costs in the dairy sector, and meat revenue minus compound feed costs in fattening pig sector.

\section{S.2 Complementary results}

Gross margin insurance programmes are relatively new and actual experience with gross margin insurance programmes is limited. All schemes use non-farm-specific triggers to limit moral hazard and adverse selection. Farm-level triggers (e.g. farm yields and sales prices) are not used in practice. Despite substantial subsidies, farmers' interest in gross margin insurance programmes (besides opting for a catastrophic coverage) is limited. An important reason might be the use of non-farm-specific triggers.

The quantitative analyses within each sector revealed that there is substantial heterogeneity between farms in terms of gross margin and its volatility. Differences in gross margin stem not only from sales prices received and input prices paid, but also from the difference in the underlying technical results determining the efficiency of production (i.e., the amount of variable inputs required to produce output). Smaller farms are associated with statistically significant larger volatility in the case of the fattening pig sector, but farm size effect was absent in the dairy sector. In both sectors analysed there is no association between gross margin volatility and other parameters analysed (i.e., family farm income and financial leverage). This implies that gross margin insurance does not target specific groups of dairy farmers, while it targets more specifically smaller fattening pig farms.

\section{S.3 Method}

Six prominent margin protection instruments are analysed in more detail. Four programmes have been established in the US (three for livestock and one for crop commodities). The two programmes referring to the EU are pilot programmes, i.e. one for fattening pigs (pilot in Belgium and the Netherlands which is not prolonged) and one for cereals (pilot in France since 2015). 
The empirical study to determine the effectiveness of gross margin insurance presented in this study is based on panel data analysis, using a sample of Dutch agricultural farms included in the Farm Accountancy Data Network (FADN) of Wageningen UR in the Netherlands. The potential impact of alternative gross margin insurance schemes is derived for each farm in the panel and quantified in terms of risk reduction as well as expected annual pay-out per farm. For each sector alternative trigger levels are analysed. Moreover, the impact of a farm-specific approach versus a national-based approach is explored. 


\section{Introduction}

Two approaches

The systemic instability of agricultural markets has always been a key factor in agricultural policies. Two approaches have traditionally been applied by public bodies to protect against agricultural price volatility (Galtier et al., 2012). The first approach is based on the stabilisation of prices, in particular by means of measures of public intervention (i.e., internal price support, aids and refunds, control supply, border tariffs). The second approach consists of mitigating the effects of volatility on agricultural incomes. This approach privileges the use of decoupling aids, safety nets for incomes and risk management tools (i.e., insurance schemes, mutual funds and/or futures markets). As a result of the successive reforms (MacSharry reform of 1992, Fishler reform of 2003, and the 2013 reform establishing a new CAP for the 2014-2020 period), the CAP has been progressively focused on more market orientation. In this context, the EU places particular emphasis on the potential role of risk management tools to cope with volatility and in stabilising agricultural incomes (European Parliament, 2015A).

Income stabilisation tools

In the current CAP (2014-2020) the risk management toolkit entails animal and plant insurance (art. 37), mutual funds for animal and plant diseases and environmental incidents (art. 38), and income stabilisation tools (art. 39) in the form of mutual funds to address income volatility. In April 2015, 13 Member States implemented one or more risk management measures under articles 37-39, which mostly focused on subsidised animal or plant insurance. For example, the Netherlands allocated funds to the new toolkit of a multi-peril crop insurance under art. 37, while income stabilisation tools under art. 39 were not considered. The question arises why income stabilisation tools under art. 39, and more specific gross margin insurance programmes, were not (yet) considered. Also, many Member States have chosen not to make use of the 'risk management toolkit' despite the possibility of co-financing under rural development (and previously under direct pay-outs). More specifically, the income stabilisation tool has so far only been programmed in Hungary, I taly, and the region of Castilla y Leon (Spain). For these aforementioned Member States programmed public expenditures on the income stabilisation fund amounted $€ 97 \mathrm{~m}$ in Italy, €19m in Hungary and $€ 14 \mathrm{~m}$ in the Spanish region Castilla y León (European Parliament, 2015B). The concept of an income stabilisation tool is to compensate farmers who experience a severe income drop, compared to the individual's average annual income of the three preceding years (or Olympic average of the previous five years). Income in this case refers to total revenue received from the market minus input costs. The income compensation would be paid regardless of the cause of the income variation, be it yield variation, price fluctuation, or higher input costs. Note that aforementioned Member States have programmed substantial budget for an income stabilisation tool, but the precise design of the envisaged tool, adoption rate and impact on farm incomes is unclear to the authors.

Instead, most Member States continue their national schemes under the State aid rules, deploy other policy instruments, or leave it up to business demand in the private sector (European Commission, 2016).

Risk and risk management instruments

Against this background, several circumstances and recent crisis events induced the need for having a closer look at risks and risk management instruments across Europe (and beyond), in particular (European Commission, 2016):

- The Commission shall present a report on the implementation of the risk management toolkit under rural development policy to the European Parliament and the Council not later than 31 December 2018.

- The question on how to contribute best to farm income stability (and level) has always been a fundamental question within the CAP. It has gained renewed attention due to budgetary constraints in light of other emerging political priorities and - more recently - persisting pressure on agricultural markets. On top of existing instruments, there are those which have not been thoroughly analysed until now (European Commission, 2016). 
The income stabilisation tool constitutes the CAP's first foray into the domain of income insurance, following the features of US agricultural policy to facilitate insurance against declining market prices. Besides revenue-based insurance schemes, gross margin insurance schemes are gaining momentum. Gross margin insurance uses reported prices, such as futures prices or prices from (local) statistical offices, to determine the expected gross margin and the actual gross margin. Amounts, e.g. for feed and livestock weights, are generally based on normative averages. The sales prices received at the local market are not used in these calculations. Farmers can choose insurance deductibles themselves within a certain range, and an indemnity is paid at the end of insurance period if the actual gross margin is less than the expected gross margin (minus the deductible).

Livestock gross margin insurance policies provide protection against the loss of gross margin, i.e. output value minus variable costs. As such, gross margin insurance provides protection when input costs rise or output prices drop. Reviewing the recent past in the Netherlands (Figures 1.1-1.4), reveals that input prices and output prices are both volatile in for example the dairy and pork industry (e.g., market value of milk and feed costs in dairy farming, and market value of fattening pigs and feed costs in fattening pig farming).

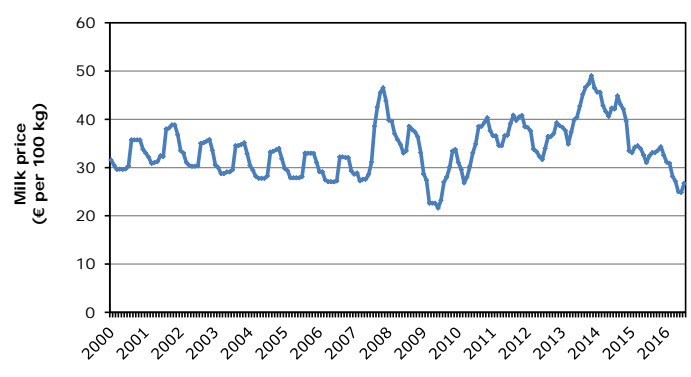

Figure 1.1 Monthly milk price Source: Wageningen Economic Research.

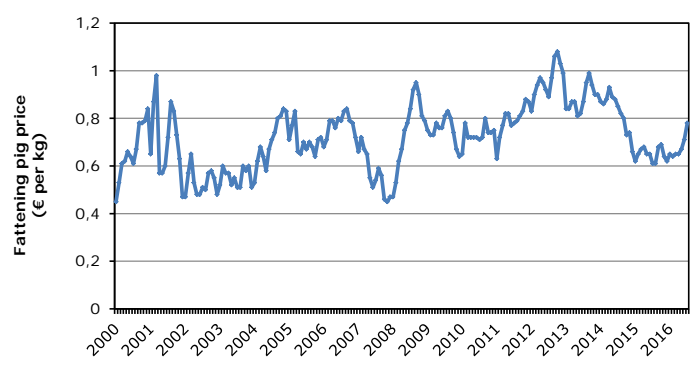

Figure 1.3 Monthly fattening pig price Source: Wageningen Economic Research.

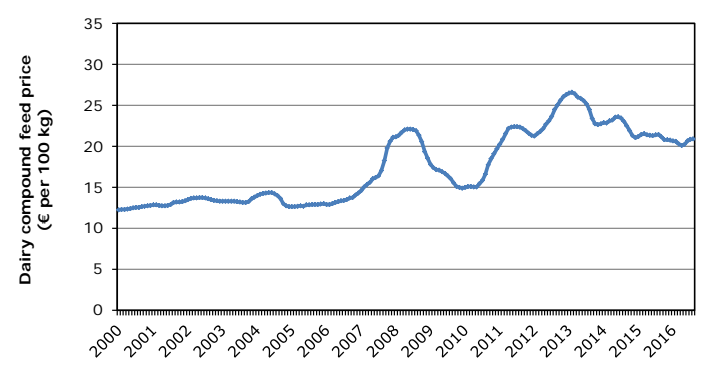

Figure 1.2 Monthly dairy compound feed price Source: Wageningen Economic Research.

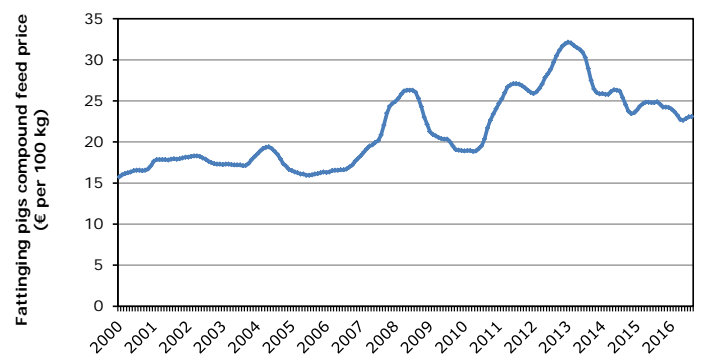

Figure 1.4 Monthly fattening pig compound feed price

Source: Wageningen Economic Research.

The objective of this report is to develop an understanding of the volatility in gross margin and the potential impact of margin insurance to reduce gross margin volatility in Dutch agriculture (see Appendix for volatility in family farm income). Of specific interest are livestock gross margin insurance for dairy and fattening pigs. More specifically the objectives are to analyse:

1. The potential role that livestock gross margin insurance for dairy and fattening pig farms can play to stabilise farm incomes within CAP; and

2. To suggest future CAP developments (2021-2027) related to livestock gross margin insurance in order to deal more effectively with income uncertainties and market volatility. 


\section{Review of margin insurance}

\section{$2.1 \quad$ The concept}

Margin insurance is a relatively new type of insurance covering the revenue of a commodity minus its costs of production. Based on the design, two types of margin insurance can be distinguished in practice. The first model ('Model $A$ ' in Figure 2.1) focuses on market volatility by considering fluctuating sales and input prices. It covers the margin between sales price and costs of production. Besides the input price, e.g. for animal feed, the other parameters of costs of production (i.e. amount of inputs required and volume produced) are kept fixed. Pay-outs are triggered if the actual margin is lower than the guaranteed margin. The size of the pay-out is based on the difference between the guaranteed margin and the actual margin.

In the second model ('Model B') both market and yield volatility are considered. The insured margin is based on the difference between revenues and costs. To estimate costs, the amount of inputs is fixed and e.g. based on normative values. (A third margin insurance concept potentially covers both market and yield volatility with none of the parameters being fixed. This constitutes the concept underlying the income stabilisation tool as mentioned in the introduction.)
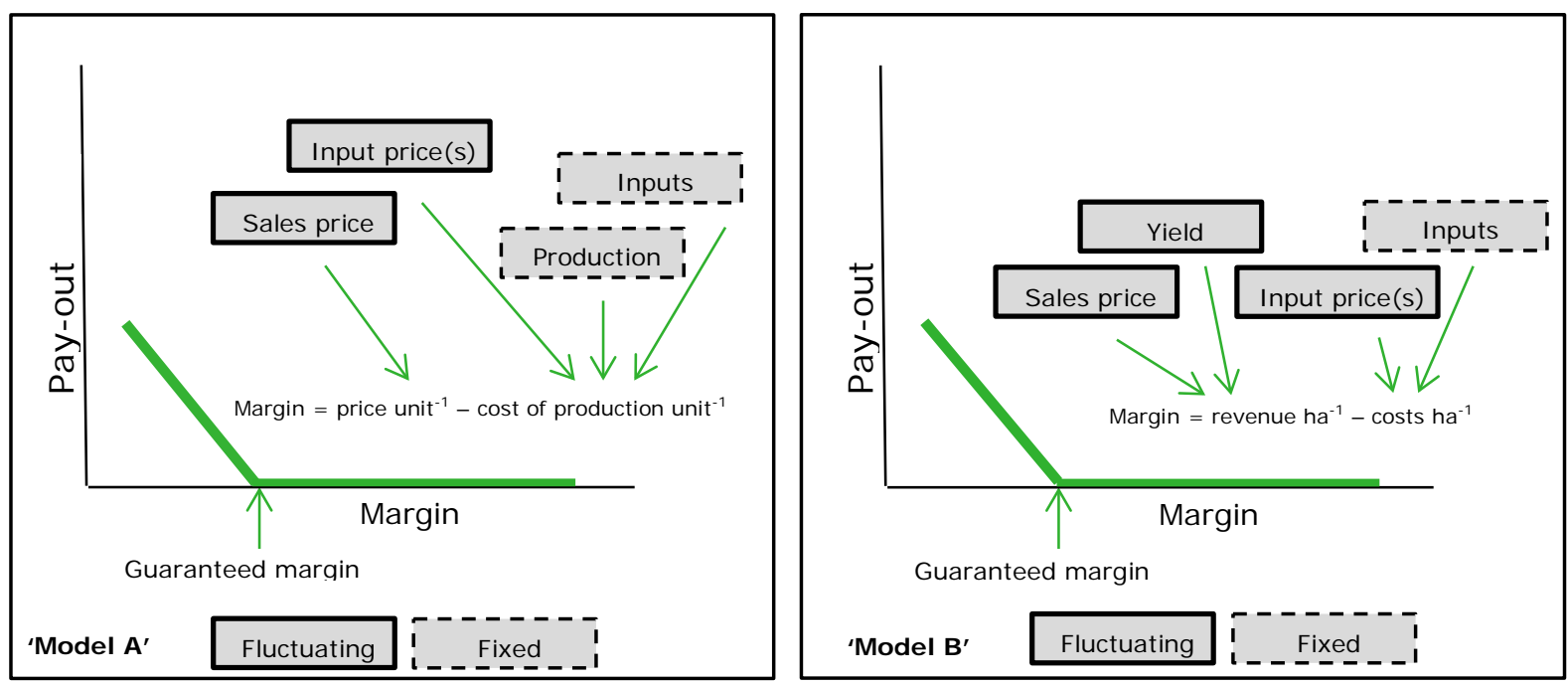

Figure 2.1 Margin insurance covering market risk ('Model $A$ '), and a combination of market and yield risk ('Model B')

Estimation of price levels

To prevent adverse selection, insurers need reliable data to establish accurate prices as part of the premium rate calculation. In this regard it is important to consider the existence of price cycles (especially with respect to livestock commodities). Insurers should therefore use actual market information (including forecasts) as much as possible, to complement historical price series data. Futures markets may be helpful instruments to establish price levels. Price cycles are also a reason for reconsidering the level of prices each year. If commodities are however not reasonably uniform and a wide variety of different grades (and different price levels) exist, the establishment of prices may be difficult.

In addition, insurers need a reliable measure of the actual price of a commodity of a certain grade at harvest or sale time, as well as a measure of input prices. Realised prices by individual farmers are likely to be problematical since they are too much influenced by the management of the insured. 
Observed spot market prices can be useful for well-functioning markets with a good reporting system. Well-functioning markets are those with a high degree of market integration, meaning that prices for the same commodity or input in different places are closely similar. For this to happen, price information needs to be public. In case prices are not highly correlated across farms, there will be considerable basis risk for farmers contemplating buying insurance.

Estimation of yield levels

With respect to livestock commodities, establishing the level of yields is likely to be problematic as yield fluctuations, especially in intensive livestock, are much more a management issue than for crops (for which weather-related events cause part of the fluctuation). This implies extra difficulties of moral hazard for the insurer. Also, most livestock commodities do not have a clear 'harvesting' time, as with crops. Livestock farms either produce output throughout the year (e.g. fattening pigs) or have a multiyear production cycle (e.g. beef cattle). Moreover, the timing of 'harvesting' for some livestock systems is somewhat flexible. Both aspects may allow insured farmers to manipulate the timing of sales in order to make a claim on the insurer.

With regard to crops, if individual farm yields are to be used, insurance instruments such as deductibles, no-claim bonuses, monitoring the behaviour of individual insureds (good farming practices), and the monitoring of crops just before or at harvest time are necessary to reduce the moral hazard problem inherent to the use of farm-level data. Yields calculated on an area index basis (rather than individual farm or field yields) cannot be influenced much by the individual farmer and could therefore be a good basis for insurance. However, the latter is only true if the area yields can be measured reliably. Furthermore, for reasons of basis risk for farmers contemplating buying insurance, area-yield data can only be used in insurance contracts in areas where yields are highly correlated across farms. Similar issues are relevant if weather-based indices are used.

Estimation of joint distributions

For insurers to set adequate premiums, they need reliable information not only on the separate parameters but also on the joint distribution of sales prices and cost of production (Model A), and of sales prices, cost of production and yields (Model B). Since sales prices and cost of production (Model A), and sales prices, cost of production and yields (Model B) may not be stochastically independent, the information needs to derive the full joint distributions are considerable. An extra difficulty arises if the nature of that stochastic dependency changes over time, e.g. as a result of market liberalisation.

From a farmer's point of view the consideration of joint distributions results in forms of insurance that cover losses at a higher level of aggregation (i.e. margins as opposed to output prices only). Conceptually, this leads to insurance schemes which are more appealing to farmers since such schemes are closer to farm income, and, hence, to the economic well-being of a farm family (Meuwissen et al., 2003). Moreover, as joint distributions take into consideration the correlations between parameters this implicitly means that the insurance is less costly compared to instruments covering these parameters independently.

\subsection{Role of public sector}

Regardless of the exact commodities, the risks covered (price and yield risks) refer to risks that are largely systemic. This implies that traditional reinsurance capacity may not be sufficiently available for margin insurance programmes. For this reason, some form of public-private partnership may well be necessary for insurers to enter this market. This is illustrated in the right-hand side of Figure 2.2, i.e. highly correlated (systemic) risks are generally regarded as not insurable through the commercial market. $^{1}$

${ }^{1}$ Correlated risks such as price and interest rate fluctuations are typically dealt with on futures markets, if available. 
This is where governments frequently intervene in risk handling in order to enhance the supply of insurance and to promote insurance markets for risks that are potentially tradable but where the market has not developed due to market failures and informational inefficiencies. These policies seek to enhance the insurability of risks through different private-public partnership arrangements so as to extract at least some of the insured's willingness to pay and co-finance protection that could otherwise fall within the sole responsibility of the public sector in case of disaster relief.

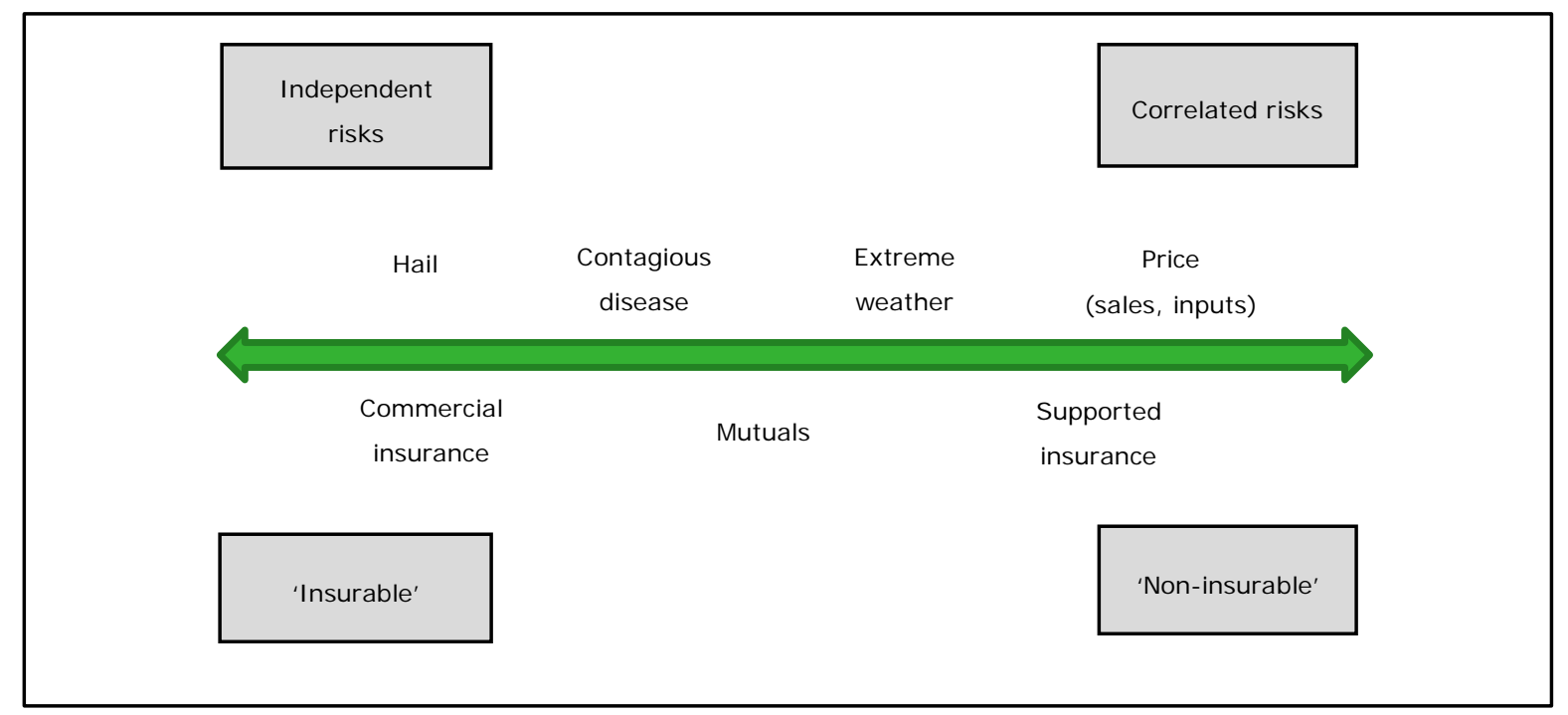

Figure 2.2 Insurability of agricultural risks

Besides direct involvement in insurance programmes, public-private partnerships can also entail government incentives for price transparency, including collection and dissemination of information on price levels and price drivers such as (local and international) storage levels. Price transparency potentially enhances the development of futures markets, which, in turn, can either be directly used by farmers to cope with price risk or they can provide price indexes for e.g. margin insurance. The availability of price information can also positively influence contract decisions between chain actors, such as with regard to price swaps, milk guarantee contracts and price pooling mechanisms (Assefa et al., 2016).

A related area of potential government involvement is farmer education and training of farmers to use price information and price risk management instruments such as futures (Veerman et al., 2016). Farmers have often argued that they find the use of futures markets to be cumbersome.

\subsection{Experience}

Actual experience with margin insurance programmes is relatively limited. Table 2.1 shows six margin protection instruments which are analysed in more detail. Four of the six programmes have been established in the US (three for livestock and one for crop commodities). The two programmes referring to the EU are pilot programmes, i.e. one for fattening pigs (pilot in Belgium and the Netherlands which is not prolonged) and one for cereals (pilot in France since 2015).

With regard to the data used to parameterise margins, Table 2.1 illustrates that none of the schemes uses farm-specific data. For instance, price levels are based on futures prices (for cattle and corn in cattle gross margin insurance, hogs and feed components in swine gross margin insurance and DLV pilot, and for cereals in cereal margin insurance), or reported statistics and projections (for feed and milk prices in dairy margin protection programme, price of nitrogen in cereal margin insurance, and sales and input prices in the margin protection programme for crops). Yields (only covered in the 
margin protection programme for crops) are based on county yields. Fixed parameters, such as cattle and pig weights, amount of feed per kg of meat or milk, and amount of inputs per ha are based on normative averages.

The table also shows that all US programmes receive subsidies from the government (although no details could be found for the livestock gross margin for swine insurance). The analysed two pilots in the EU are without subsidies. Subsidised insurance may distort market signals to farmers. For the dairy margin protection programme this has been described by Bozic et al. (2014). They argue that farmers who do not receive the right market signals do not respond to changing market circumstances in time, therewith likely leading to prolonged periods of low margins. In line with this, Mark et al. (2016) discuss that the substantial risk reductions provided by the dairy margin protection programme can positively impact production levels, although risk elasticities (percentage production changes in response to percentage changes in levels of risk) have been found to be relatively small. They also argue that the dairy margin protection programme can best be described as partly decoupled, because pay-outs are not triggered by a farmer's production level, but they are impacted by current market conditions (i.e. milk and feed prices).

With regard to farmers' interest in margin insurance, Table 2.1 shows that farmers are generally not very interested in this type of coverage. Participation is highest in the dairy margin protection programme in which $55 \%$ of US dairy farms are participating (reflecting $80 \%$ of US milk). The majority (77\%, June 2016) opted for the catastrophic coverage for which they only have to pay an enrolment fee of $\$ 100$ (€94) per farm ${ }^{2}$ for an insured margin of $\$ 4$ per CWT (€8.3 cent per $\left.\mathrm{kg}\right)^{3}$. Twenty percent bought additional coverage (i.e. 'buy-up' coverage) up to a margin of $\$ 6.50$ per CWT $(€ 13.5$ cent per $\mathrm{kg}$ ). Less than one percent of farmers bought the highest level of buy-up coverage, i.e. up to a margin of $\$ 8$ per CWT ( $€ 16.6$ cent per $\mathrm{kg}$ ). Buy-up coverage is differentiated to farm size. Farms exceeding 4 million lbs milk ( 1.8 million $\mathrm{kg}$ ) pay a higher premium per unit ${ }^{4}$. Farmers' relatively low overall interest in margin insurance contrasts prior expectations (see section 2.1 under 'joint distributions' for one of the explanations). A possible explanation might be the use of observed (e.g. national) parameters instead of farm-specific parameters. In addition, for the hedging pilot for the pig sector, DLV (2015) indicated that Dutch and Belgium pig chain actors perceived the hedging instrument to be too complicated. Also the low liquidity on the pork market was one of the reasons for discontinuation of the pilot programme. ${ }^{5}$

\footnotetext{
Exchange rate: US $\$ 1=€ 0.94$.

$1 \mathrm{CWT}=45.35 \mathrm{~kg}$.

4 Average production in the Netherlands: 990,000 kg milk per farm (Flynth, 2016).

A recent price risk management innovation in the Belgian pig sector is the establishment of price swaps between pig farmers and a pig slaughterhouse (personal communication DLV, 2016).
} 
Table 2.1 Margin protection instruments in agriculture

\begin{tabular}{|c|c|c|c|c|c|c|c|}
\hline & Reference & Programme & Country & Sector(s) & Indemnity trigger & Subsidies & Participation \\
\hline \multirow{5}{*}{ 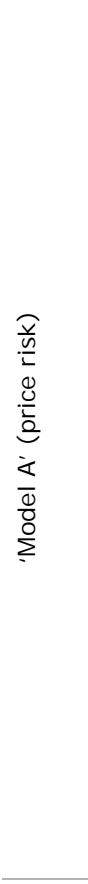 } & USDA, 2010 & $\begin{array}{l}\text { Livestock gross margin for } \\
\text { cattle insurance policy } \\
\text { (2010-present) }\end{array}$ & US & $\begin{array}{l}\text { Cattle (fattening, } \\
\text { calf finishing, } \\
\text { yearling } \\
\text { finishing) }\end{array}$ & $\begin{array}{l}\text { If actual margin (per month) is less than guaranteed } \\
\text { margin. Margins are based on CME futures prices } \\
\text { (cattle, corn). Cattle weights and amounts of feed are } \\
\text { based on normative averages. }\end{array}$ & Yes: premium (up to $50 \%$ ) & No data available \\
\hline & USDA, 2014 & $\begin{array}{l}\text { Livestock gross margin for } \\
\text { swine insurance policy } \\
\text { (2012-present) }\end{array}$ & US & $\begin{array}{l}\text { Pigs (farrow-to- } \\
\text { finish, feeder pig- } \\
\text { finishing, early } \\
\text { weaned) }\end{array}$ & $\begin{array}{l}\text { If actual margin (per month) is less than guaranteed } \\
\text { margin. Margins are based on CME futures prices } \\
\text { (hogs, corn, soybean meal). Pig weights and amounts of } \\
\text { feed are normative averages. }\end{array}$ & $?($ not on premium) & No data available \\
\hline & DLV, 2015 & $\begin{array}{l}\text { Margin protection through } \\
\text { hedging for pig sector } \\
\text { (2014-15) }\end{array}$ & $\begin{array}{l}\text { Netherlands, } \\
\text { Belgium }\end{array}$ & Pig sector & $\begin{array}{l}\text { Based on hedging on Matif (wheat) and Eurex Frankfurt } \\
\text { (pork). }\end{array}$ & No, private instrument & $\begin{array}{l}\text { Pilot from DLV, low } \\
\text { interest }\end{array}$ \\
\hline & MacDonald et al., 2016 & $\begin{array}{l}\text { Dairy Margin Protection } \\
\text { Program (2014-18) }\end{array}$ & US & Dairy & $\begin{array}{l}\text { Average national margin (the difference between the } \\
\text { U.S. all-milk price and the estimated national average } \\
\text { feed cost) below threshold for } 2 \text { succeeding months. } \\
\text { Prices of feed components (corn, alfalfa hay, soybean) } \\
\text { and milk are based on reported statistics. }\end{array}$ & $\begin{array}{l}\text { Yes: premium. For cat } \\
\text { coverage farmers pay only an } \\
\text { enrolment fee ( } \$ 100 \text { per farm). } \\
\text { Buy-up coverage for margins } \\
\text { between } \$ 4.00 \text { and } \$ 8.00 \text { per } \\
\text { cwt }^{1} \text { (differentiated to farm } \\
\text { size) }\end{array}$ & $\begin{array}{l}\text { Farms: } 55 \% \text {, Milk } \\
\text { production: } 80 \%\end{array}$ \\
\hline & $\begin{array}{l}\text { Ferenczi, } 2016 \\
\text { (personal } \\
\text { communication) }\end{array}$ & $\begin{array}{l}\text { Cereal margin insurance } \\
\text { (pilot, 2015-) }\end{array}$ & $\begin{array}{l}\text { France } \\
\text { (Champagne } \\
\text { region) }\end{array}$ & Cereals & $\begin{array}{l}\text { Based on revenues minus nitrogen cost, i.e. the cereal } \\
\text { price at sowing (closest futures date) minus an annual } \\
\text { regional average price for nitrogen. }\end{array}$ & No, private instrument & $\begin{array}{l}\text { Pilot from French } \\
\text { Coop Vivescia. Low } \\
\text { interest }^{2} \text {. }\end{array}$ \\
\hline 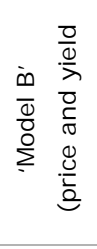 & USDA, 2015 & $\begin{array}{l}\text { Margin protection for } \\
\text { Federal crop insurance } \\
\text { (2015-present) }\end{array}$ & $\begin{array}{l}\text { Limited nu. of } \\
\text { states }^{3}\end{array}$ & $\begin{array}{l}\text { Crop (rice, corn, } \\
\text { soybean and } \\
\text { wheat) }\end{array}$ & $\begin{array}{l}\text { If operating margin (revenue less input costs) is less } \\
\text { than } 70-90 \% \text { of expected margin. Revenues are based } \\
\text { on county yields and projected commodity prices }{ }^{4} \text {. } \\
\text { Cost are based on normative quantities of each } \\
\text { allowed input (diesel, urea, phosphate, potash, interest) } \\
\text { multiplied by county price estimates. }\end{array}$ & Yes: premium & No data available \\
\hline $\begin{array}{ll}1 & \text { CWT: } \\
2 & \text { New ir } \\
{ }^{3} & \text { Rice ( } \\
{ }^{4} & \text { Details }\end{array}$ & $\begin{array}{l}\text { equivalent milk production. } \\
\text { nitiatives include turnover ins } \\
\text { selected counties): Arkansas } \\
\text { Is on price estimations are no }\end{array}$ & $\begin{array}{l}\text { surance (offered by Groupama an } \\
\text {, California, Louisiana, Mississipp } \\
\text { t available. }\end{array}$ & Missouri, Texa & $\begin{array}{l}\text { 2016). } \\
\text { corn (all counties): I }\end{array}$ & va; soybeans (all counties): Iowa, Montana, N-Dakota, S-Dakota; whe & eat (selected counties): Minnesota. & \\
\hline
\end{tabular}




\section{$2.4 \quad$ Typical example}

We use the US dairy margin protection programme to illustrate the calculation of margins (Table 2.2) and pay-outs (Table 2.3). Margins are calculated per month as illustrated in the table for the months of May till October 2014. Feed costs are based on a combination of corn, alfalfa hay and soybean prices as reported by US National Agricultural Statistics Service (NASS) and the Agricultural Marketing Service (AMS) Market News. The milk margin per pay period is the average of the margin of 2 months. Farmers are paid (if a pay-out is triggered) every 2 months. Due to the relatively high margins in the months of 2014 which are included in the table, none of the periods would have resulted in a pay-out, even not for farmers with the highest coverage level up to a margin $\$ 8$ per cwt. Matthews (2016) noted that the same was more or less true for the year 2015; a stable margin close to the $\$ 8.00$ per cwt level meant that pay-outs were made only for a limited period and only to farms who had chosen the highest level of risk protection.

Table 2.2 Estimation of milk margins per pay period (2014 figures for May-October, USDA) ${ }^{1}$

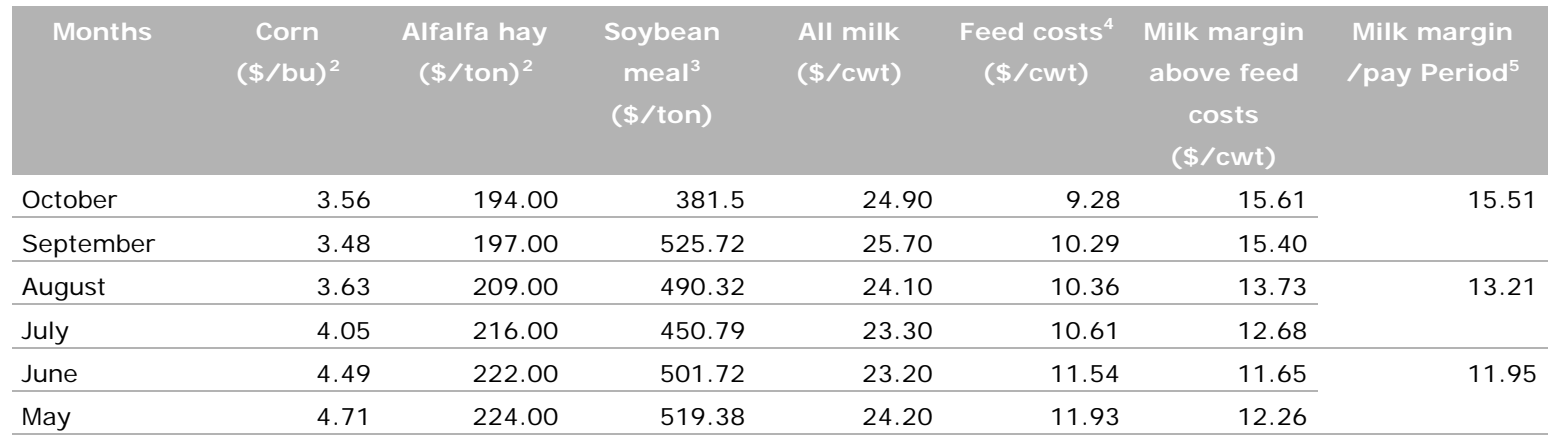

1 Rounded to two decimals.

2 As reported by the US National Agricultural Statistics Service (NASS).

3 Central Illinois soybean meal price delivered by rail as reported in the Agricultural Marketing Service (AMS) Market News.

4 Weighted average of corn, alfalfa hay and soybean meal prices.

5 At a milk margin minus feed costs of $\$ 8$ per cwt or less, pay-outs are possible depending on the level of coverage chosen by the dairy producer.

The selection of the coverage level and the calculation of pay-outs are illustrated below for a dairy farmer who bought the catastrophic coverage as well as a limited additional buy-up coverage for $50 \%$ of his production up to a margin of $\$ 7$ per cwt. 
Table 2.3 Example of pay-outs under dairy margin protection programme (based on USDA, 2016)

\begin{tabular}{|c|c|c|}
\hline I tem & Explanation & Example dairy farm \\
\hline $\begin{array}{l}\text { Production } \\
\text { history } \\
\text { establishment }\end{array}$ & $\begin{array}{l}\text { Per farm the production history is established using } \\
\text { the highest annual milk production marketed during } \\
\text { the full calendar years of } 2011,2012 \text { or } 2013 \text {. }\end{array}$ & $\begin{array}{l}\text { Established production history: } 3 \text { million lbs } \\
\text { (30,000 cwt). (This equals 5,000 cwt per } \\
2 \text { months period.) }\end{array}$ \\
\hline $\begin{array}{l}\text { Coverage } \\
\text { election }\end{array}$ & $\begin{array}{l}\text { - Catastrophic (CAT) coverage: } \$ 4 \text { margin coverage } \\
\text { at } 90 \% \text { of the established production history. This } \\
\text { coverage requires no premium pay-out (only } \$ 100 \\
\text { administrative fee). } \\
\text { - Annually, farmers can select buy-up coverage from } \\
25 \text { to } 90 \% \text { of the established production history in } \\
5-\% \text { increments and a coverage level threshold } \\
\text { from } \$ 4.50 \text { to } \$ 8 \text { in } 50 \text {-cent increments. Premiums } \\
\text { are differentiated according to Tier } 1 \text { ( }<4 \text { million } \\
\text { lbs) and Tier } 2 \text { (> } 4 \text { million } \mathrm{lbs).}\end{array}$ & $\begin{array}{l}\text { The farmer selected buy-up coverage, i.e. } \\
50 \text { percent coverage level at the } \$ 7 / \text { cwt margin } \\
\text { threshold. }\end{array}$ \\
\hline $\begin{array}{l}\text { Pay-outs per } \\
\text { two-month } \\
\text { period }\end{array}$ & $\begin{array}{l}\text { A farmer will receive a margin protection pay-out } \\
\text { whenever the average actual dairy production margin } \\
\text { for a consecutive two-month period is less than the } \\
\text { coverage level threshold selected. }\end{array}$ & $\begin{array}{l}\text { For a two-month marketing period the actual } \\
\text { production margin is } \$ 5 / \mathrm{cwt} \text {. } \\
\text { Pay-out for the two-month period: } \\
\text { - } \$ 7 \text { threshold minus } \$ 5 \text { margin }=\$ 2 \text { difference } \\
\text { - } \$ 2 \times 50 \% \times 5,000 \mathrm{cwt} .=\$ 5,000 \text {. }\end{array}$ \\
\hline
\end{tabular}

To summarise, the key characteristics of the dairy margin protection programme are:

- Margins are based on difference between sales price and cost of production (compare 'Model A');

- Cost of production is based on fluctuating feed prices and fixed input and production levels;

- Margins are estimated per 2-months period;

- Pay-outs are considered every 2 months;

- Farmers can buy 'buy-up coverage', i.e. additional coverage on top of catastrophic coverage;

- Premium rates for buy-up coverage are differentiated according to farm size. 


\section{Potential impact of margin insurance in the Netherlands}

\subsection{Data analysis}

A descriptive panel data analysis is conducted to analyse the heterogeneity of volatility of key variables (i.e., input price, output price, and gross margin) per sector (i.e., dairy and fattening pigs). Furthermore, by means of simulation the potential impact of a margin insurance is analysed.

The cases used in this study were derived from a sample of Dutch agricultural farms included in the Farm Accountancy Data Network (FADN) of Wageningen Economic Research in the Netherlands (Diederen, Meijl et al., 2003; Lans, van Galen et al., 2014). This is a representative sample of the agricultural sector in the Netherlands. Specialised farms were selected for each sector analysed only from this stratified sample if at least $67 \%$ of the standard gross margin originated from the main activity (Vrolijk et al., 2010). The analysed sample consisted of 553 farms. Annual nominal price data from an unbalanced panel for the period 2001-2015 were used. Farms participate in the panel on average for 7 years.

The coefficient of variation (CV) is used as a proxy for volatility. The coefficient of variation is a standardised measure of dispersion. It is often expressed as a percentage, and is defined as the ratio of the standard deviation to the mean (or its absolute value). By doing so, it allows for meaningful comparison between two or more magnitudes of variation, even if they have different means (e.g., revenues versus gross margin) or different scales of measurement (e.g., yields in kg versus prices in $€)$. Gross margin volatility, and coefficient variation, differs substantially between and within agricultural sectors. In the current study we report median (the 50 percentile value) CVs to estimate the central tendency. In the study of Vrolijk et al. (2009), Tukey M-estimators were used whereby weighting the observations was based on their deviation from the mean, but these are intuitively more difficult to comprehend. Mediums and M-estimators have both the advantage that they are less sensitive to outliers or extreme values in the data set than average values. Note that CVs are not an ideal index since if the mean value is close to zero, the CV will approach infinity and is therefore sensitive in these cases to small changes in the mean (arbitrarily the maximum level is set at $250 \%$ ) (Van Asseldonk and Van der Meer, 2016).

The potential impact of alternative gross margin insurance schemes is derived for each farm in the panel and quantified in terms of CV as well as expected annual pay-out per farm. For each sector four alternative deductibles are analysed. Moreover, the impact of a farm-specific approach versus a national-based approach is explored. Note that the US dairy policy under the 2014 farm bill is an insurance programme based on national milk and feed prices, despite considerable regional variation in feed costs and milk prices (Miller, 2016).

Gross margin volatility with or without insurance is presented by means of the median, P20 (the 20 percentile value) and P80 (the 80 percentile value). In any given year $60 \%$ of the businesses then record a farm gross margin which lies within the P20-P80 range, whilst $20 \%$ record a household income greater than the P80 level and a further 20\% record a household income lower than the P20 level. 


\subsection{Gross margin volatility}

\subsubsection{Dairy sector}

The two relevant gross margin factors are the farm-gate milk and compound feed prices (given gross margin 'Model A'). In dairy farming, lowest average gross margins were observed in 2009

(Figure 3.1A) as a result of unfavourable developments in the prices of milk prices and dairy products (Figure 3.1B). The factory price of milk and the feed concentrate price tend to move in a similar direction (J ongeneel and Van Berkum, 2015). Higher milk prices are offset by higher feed costs, and vice versa, and this positive correlation smoothens gross margin. This phenomena is captured by higher CV values for variable costs in comparison to gross margin. The cyclical fluctuations of supply and prices in livestock markets can be rationalised based on production lags and adaptive expectations.
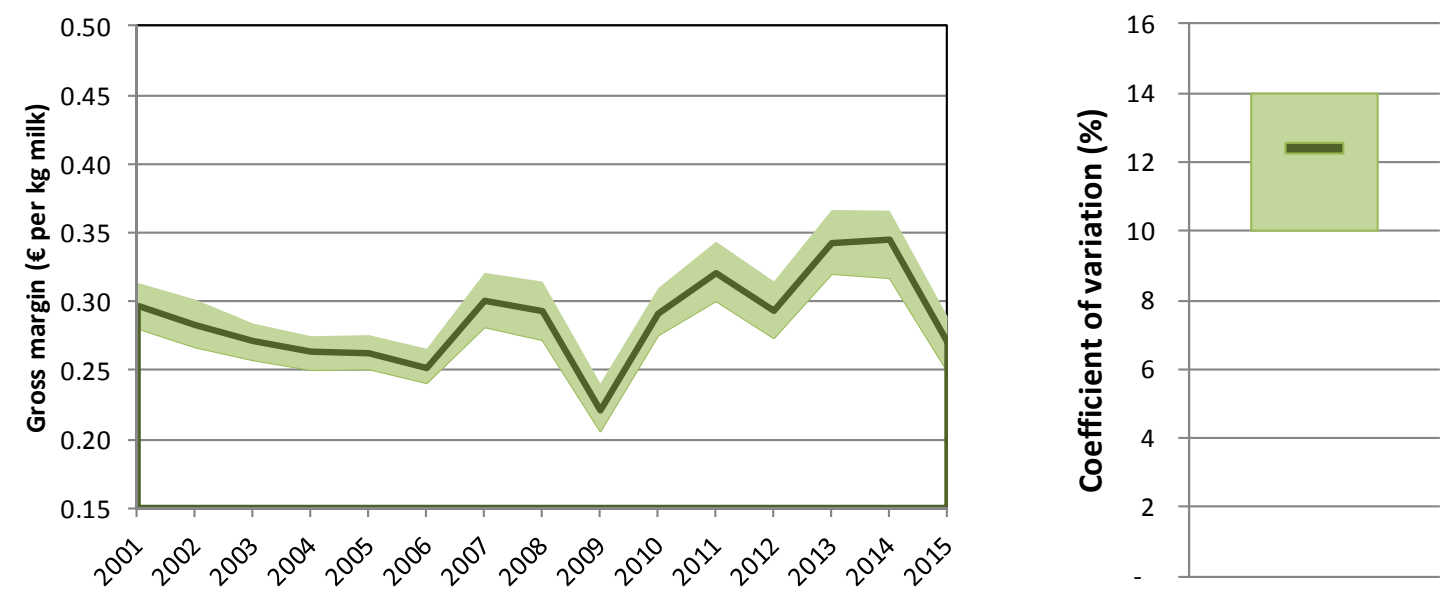

Figure 3.1A Gross margin volatility and coefficient of variation on dairy farms ( $p 20$, median, p80)
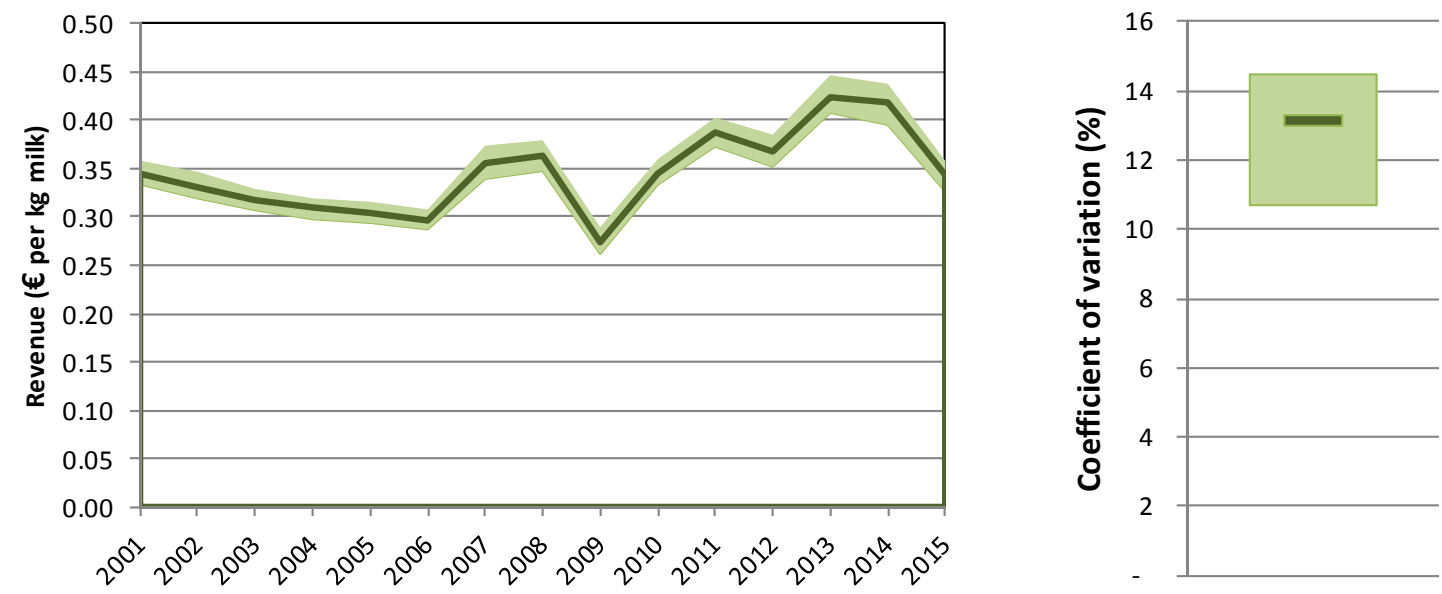

Figure 3.1B Milk price volatility and coefficient of variation on dairy farms ( $p 20$, median, p80) 

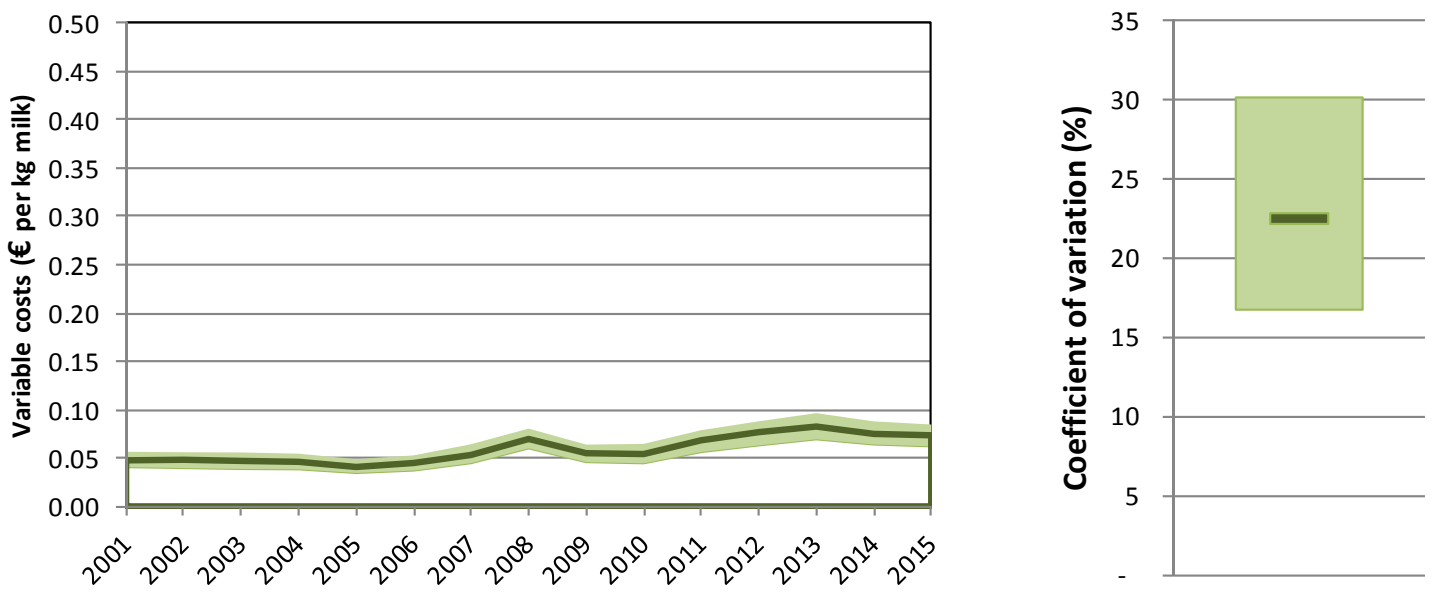

Figure 3.1C Variable cost (compound feed) volatility and coefficient of variation on dairy farms ( $p 20$, median, p80)

In the past nominal milk prices were more or less stable under the EU milk support price programme and the milk quota system. From 2004 onwards, EU milk price support was gradually reduced from $€ 0.283$ per $\mathrm{kg}$ milk equivalent down to $€ 0.217$ per $\mathrm{kg}$ milk equivalent in 2008 . The milk quota system was abolished from 1 April 2015 onwards. It is clear that milk prices and dairy products in the EU will become more volatile as a response to the transformation of the classical price support regime of the CAP into a safety net provision. As a result, prices for dairy products in the EU are increasingly related to world market prices, and are also affected by the volatility of these prices (J ongeneel and Van Berkum, 2015). For the analysed time horizon there is an upward trend for variable costs (Figure 3.1C).

More in-depth analysis was conducted by splitting the sample in two equivalent portions to compare farms with relatively low versus high gross margin volatility. Farm characteristics analysed comprised standard output, herd size, land size, family farm income and financial leverage (Table 3.1). None of the analysed factors differed significantly (T-test) between the two subsamples. This implies that gross margin insurance does not target specific groups of dairy farmers.

Table 3.1 Relative gross margin volatility and dairy farm characteristics a)

\begin{tabular}{lrr} 
& Low CV & High CV \\
Standard Output (SO) & 480,875 & 448,094 \\
\hline Herd size (number of dairy cows) & 130 & 118 \\
\hline Land size (hectare) $^{1}$ & 68 & 66 \\
\hline Family farm income (€ per year) & 53,313 & 44,800 \\
\hline Financial leverage rate (proportion of equity in the total assets) (\%) & 65
\end{tabular}

a) Not significant at $5 \%$ level. 


\subsubsection{Fattening pig sector}

The fattening pig farming sector suffered from the economic recession which started in 2007-2008. Deprived market prices for pig meat in combination with higher input costs of animal feed have put additional extra pressure on farmers' incomes (Figure 3.2). More recently, pig farm gross margin decreased in 2014 again primarily as a result of lower revenues in that year and higher feed costs since 2011 . Feed costs account for $60 \%$ of total paid costs and depreciation on pig farms (www.agrimatie. $\mathrm{nl}$ ).
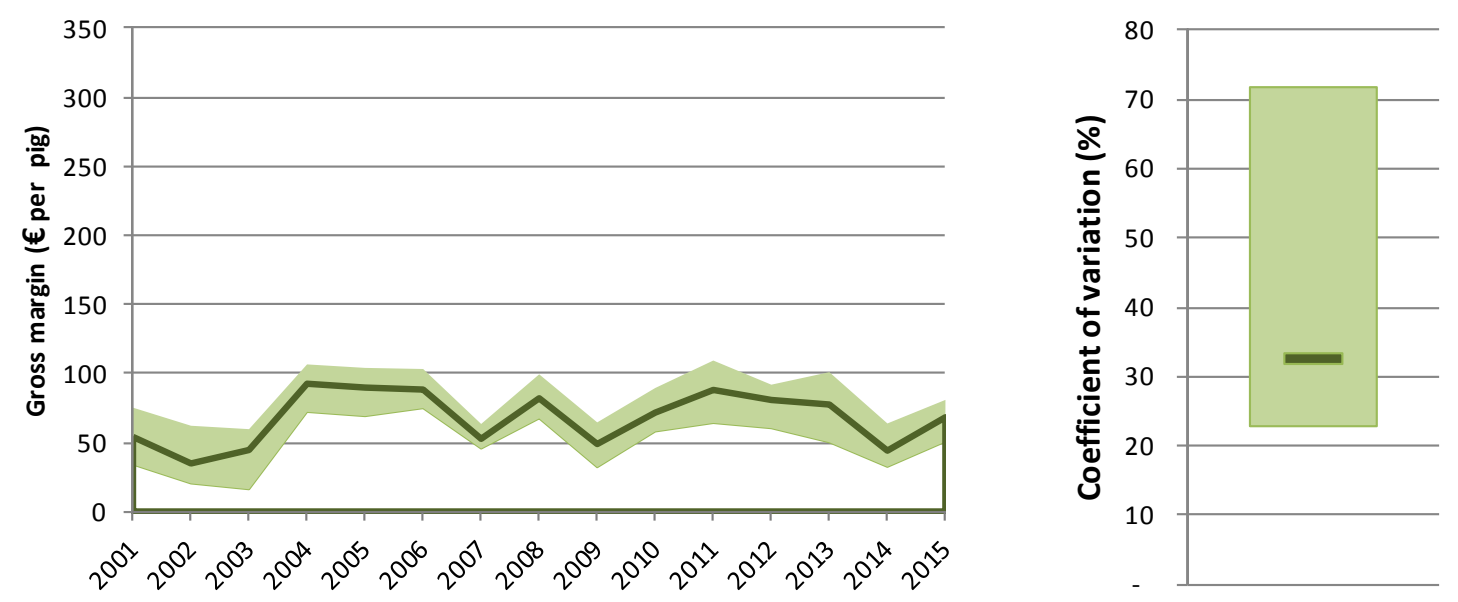

Figure 3.2A Gross margin volatility and coefficient of variation on fattening pig farms ( $p 20$, median, p80)
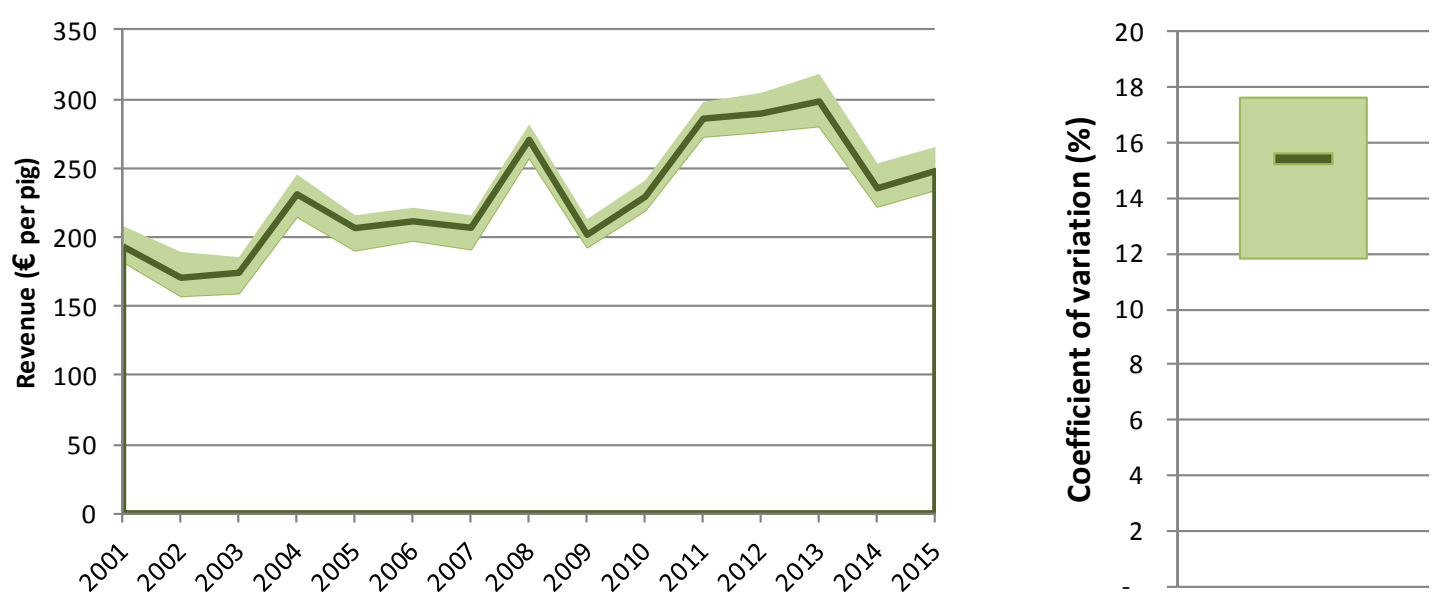

Figure 3.2B Meat price volatility and coefficient of variation on fattening pig farms ( $p 20$, median, p80) 

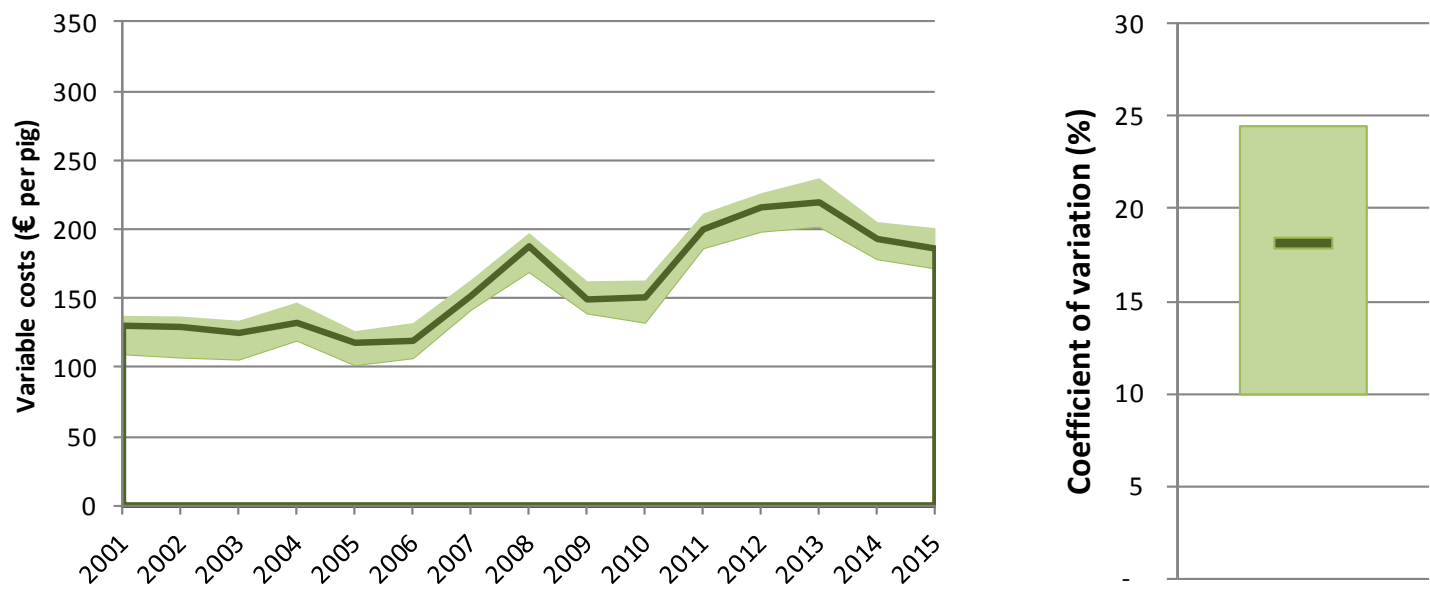

Figure 3.2C Variable cost volatility and coefficient of variation on fattening pig farms ( $p 20$, median, p80)

More in-depth analysis was conducted by splitting the sample in two equivalent portions to compare farms with relative low versus high gross margin volatility. Farm characteristics analysed comprised standard output, herd size, family farm income and financial leverage (Table 3.2). In general pig farms with higher gross margin volatilities were significantly smaller (T-test). Differences in gross margin, and volatility thereof, are largely determined by farm management decisions affecting underlying technical results determining the efficiency of production (i.e., the amount of variable inputs required to produce output). At the same time, better managed farms are likely those farms that have expanded their farming operations.

Table 3.2 Relative gross margin volatility and pig farm characteristics

\begin{tabular}{lrr} 
& Low CV & High CV \\
Farm size (SO) a) & $1,050,414$ & 630,328 \\
\hline Herd size (number of fattening pigs) a) & 3,766 & 2,234 \\
\hline Family farm income (€ per year) & 28,821 & 36,818 \\
\hline Financial leverage rate (proportion of equity in the total assets) (\%) & 57 & 65 \\
\hline
\end{tabular}

a) Significant at $5 \%$ level. 


\subsection{Potential impact gross margin insurance}

\subsubsection{Dairy sector}

As a starting point to study the impact of gross margin insurance on annual fluctuations, farm-specific gross margins are calculated based on a threshold of $€ 0.25$ per $\mathrm{kg}$ milk (i.e., coverage level threshold). The insurance is furthermore assumed to protect $100 \%$ of the established production history (i.e., coverage level percentage). The coverage level threshold and coverage level percentage are applicable for each calendar year and premiums are not accounted for (Figure 3.3).

In general, the ability to smoothen volatile prices with this threshold, in absolute terms of CV values, is relatively limited. A complementary risk measure is the impact of insurance on the downside-risk of the gross margin probability distribution (i.e., protection against the risk of gross margins below thresholds). For example, all dairy farmers would have received a margin protection pay-out in 2009 had the margin insurance been in effect to guarantee a minimum margin of $€ 0.25$ per $\mathrm{kg}$ milk.
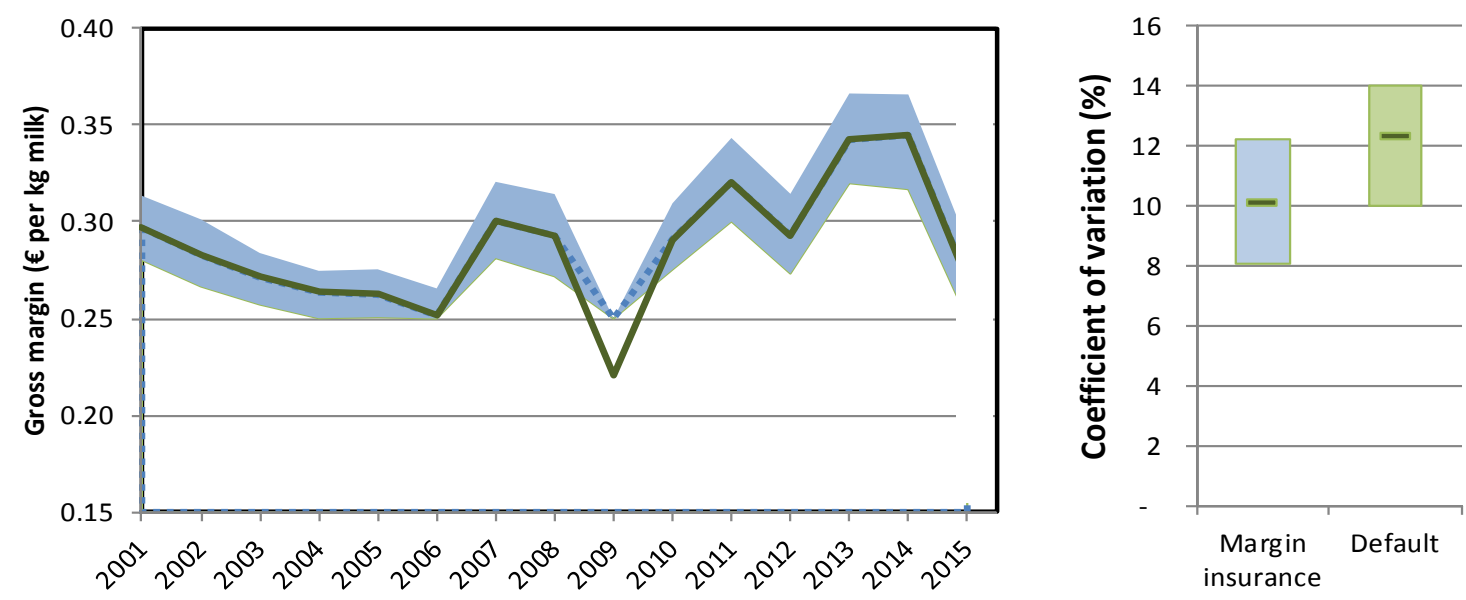

Figure 3.3 Gross margin insurance with threshold level of $€ 0.25$ per kg milk on dairy farms (p20, median, p80, green line represents median of default without gross margin insurance)

Subsequently, the impact of four alternative coverage levels was studied. The coverage level threshold ranged from $€ 0.15$ per $\mathrm{kg}$ milk to $€ 0.30$ per $\mathrm{kg}$ milk in 5-eurocent increments. Given a threshold of $€ 0.25$ per kg milk, the median volatility of gross margin decreases (17\%), while dairy farmers receive an average annual pay-out of 0.4 eurocent per $\mathrm{kg}$ milk (Table 3.3). Taking into account farm size, farmers receive an average pay-out of $€ 2,438$ per farm per year. Note that aforementioned expected farm receipts also quantify risk premiums needed to establish an actuarially fair premium rate.

Lower coverage level thresholds have a limited impact on gross margin volatility since pay-outs are limited (for example threshold of $€ 0.15$ per $\mathrm{kg}$ did not affect median and analysed bandwidth of CV values compared to the default situation without gross margin insurance).

Note that the simulation is based on the difference between the farm-specific milk price and the farmspecific compound feed cost. Such a farm-specific contract is not exposed to basis risk. However, basis risk will become important (Table 3.3) if the national milk price, the national average feed cost and a normative assumption of amount of compound feed used per $\mathrm{kg}$ milk produced are used for margin calculations and pay-outs (as is the case in Margin Protection Program for Dairy in the US). In case of a national-based coverage, annual pay-outs do not differ between farms. Given a threshold of $€ 0.30$ per $\mathrm{kg} \mathrm{milk,} \mathrm{in} 20 \%$ of the years all dairy farmers receive a pay-out of at least $€ 0.033$ per $\mathrm{kg}$ milk (Table 3.3). 
Table 3.3 Alternative coverage level thresholds on dairy farms

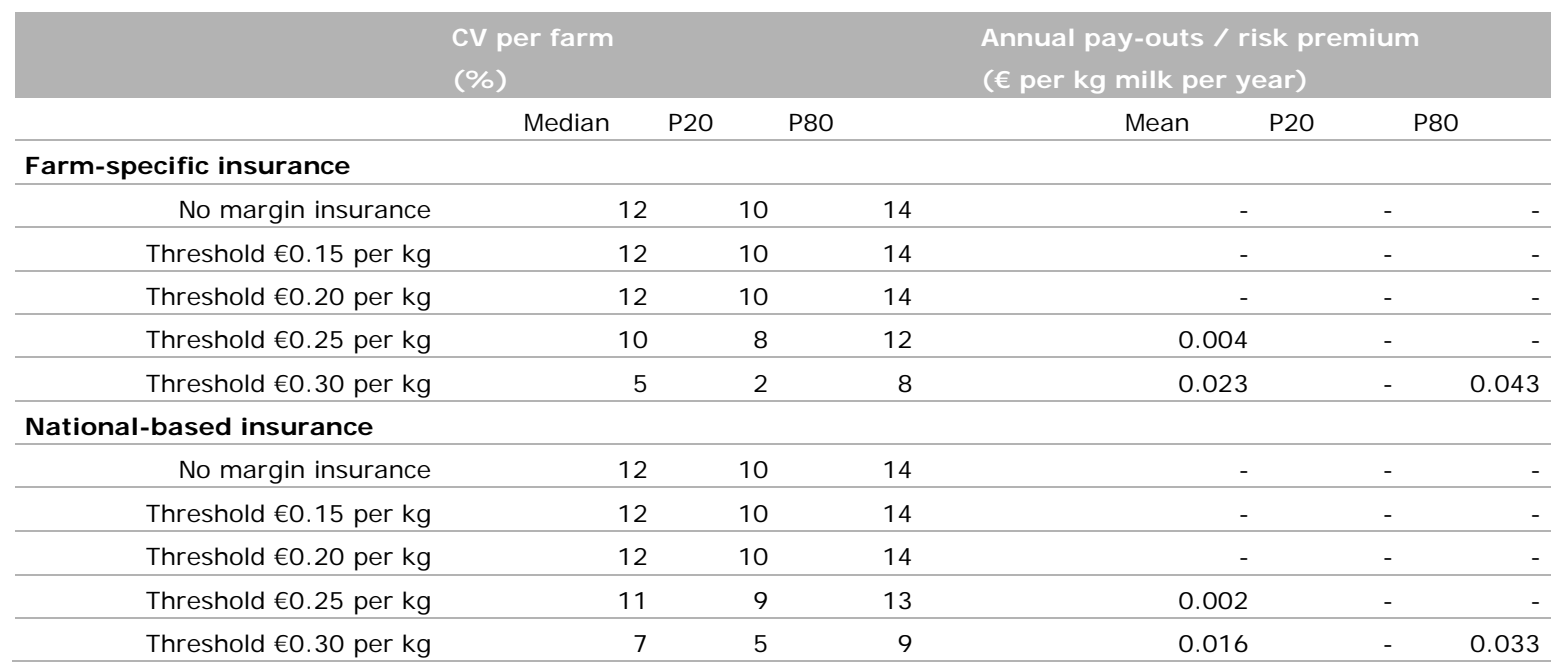

\subsubsection{Fattening pig sector}

As a starting point to study the impact of gross margin insurance on annual fluctuations, farm-specific gross margins are calculated based on a threshold of $€ 50$ per fattening pig (i.e., coverage level threshold). The insurance is furthermore assumed to protect $100 \%$ of the established production history (i.e., coverage level percentage). The coverage level threshold and coverage level percentage are applicable for each calendar year and premiums are not accounted for (Figure 3.4).

In general, with a threshold of $€ 50$ per fattening pig volatile prices are smoothened. Approximately $50 \%$ of the farmers would have benefited from pay-outs had the margin insurance been in effect in 2002, 2003, 2009 and 2014. A smaller proportion would have benefited in 2001. As a result not only the median CV value would decrease, also the bandwidth would have been narrower. Note that the simulation is based on the difference between the farm-specific pig price and the farm-specific feed cost (including a farm-specific level of amount of compound feed per $\mathrm{kg}$ meat produced).
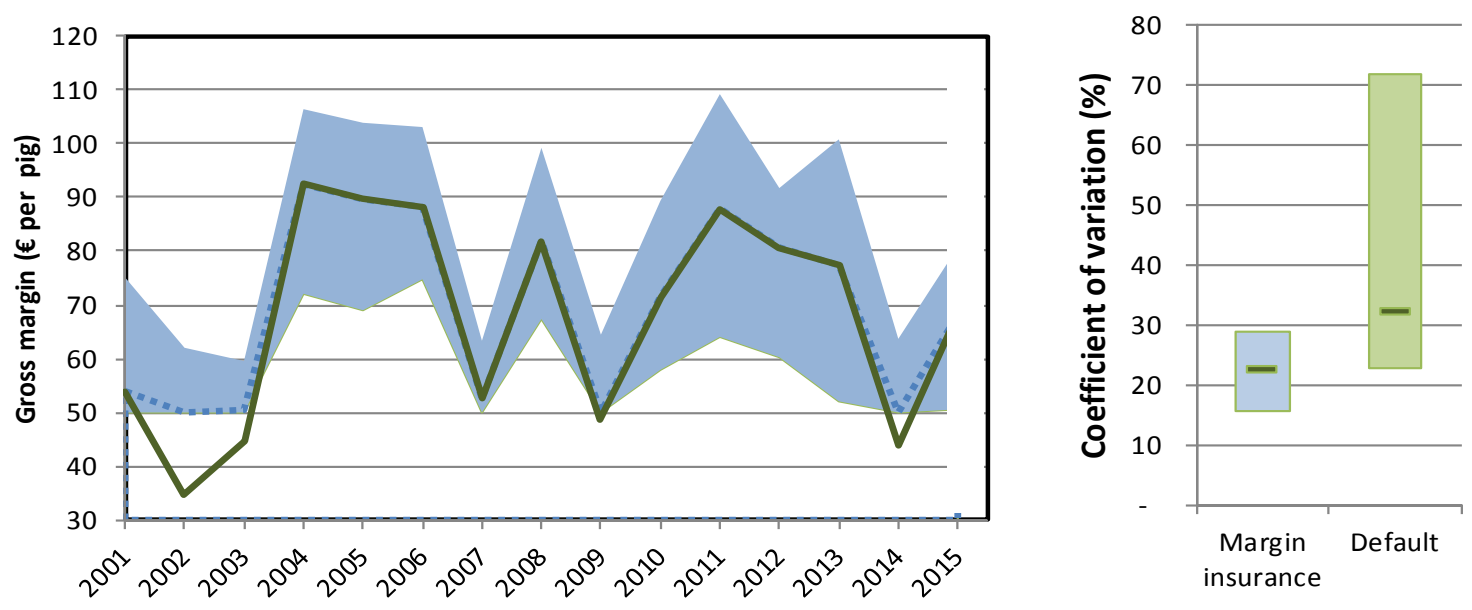

Figure 3.4 Gross margin insurance with threshold level of $€ 50$ per pig ( 220 , median, p80, green line represents median of default without gross margin insurance)

Subsequently, the impact of four alternative coverage levels was studied. The coverage level threshold ranged from $€ 30$ per pig to $€ 60$ per pig in 10-euro increments. Given a threshold of $€ 50$ per pig, the median volatility of gross margin decreases (30\%), while fattening pig farmers receive an average annual pay-out of $€ 5$ per pig (Table 3.4). Taking into account farm size, farmers receive an average 
pay-out of $€ 7,691$ per farm per year. These expected farm receipts also quantify risk premiums needed to establish an actuarially fair premium rate.

Table 3.4 Alternative coverage level thresholds on fattening pig farms

\begin{tabular}{|c|c|c|c|c|c|c|c|c|}
\hline & \multicolumn{4}{|l|}{$\begin{array}{l}\text { CV per farm } \\
(\%)\end{array}$} & \multicolumn{4}{|c|}{$\begin{array}{l}\text { Annual pay-outs per farm } \\
\text { ( } € \text { per pig per year) }\end{array}$} \\
\hline & Median & P20 & & & Mean & $\mathrm{P} 20$ & & \\
\hline \multicolumn{9}{|l|}{ Farm-specific insurance } \\
\hline No margin insurance & 32 & & 23 & 72 & & - & - & - \\
\hline Threshold $€ 50$ per pig & 23 & & 16 & 29 & & 5 & 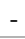 & 3 \\
\hline Threshold €60 per pig & 19 & & 10 & 23 & & 7 & 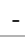 & 13 \\
\hline \multicolumn{9}{|l|}{ National-based insurance } \\
\hline Threshold $€ 50$ per pig & 29 & & 21 & 68 & & 1 & - & 1 \\
\hline Threshold €60 per pig & 26 & & 18 & 54 & & 5 & - & 11 \\
\hline
\end{tabular}

In the aforementioned approach, farm-specific characteristics are used to determine the pay-out, i.e., the output price received, the amount of inputs used and input price paid at the local market. Basis risk will become important, given the wide band of gross margin in each year between farms, if the national pig price and the national average feed cost are used for margin calculations and pay-outs (as is the case in Margin Protection Program in the US). A relatively low coverage level threshold based on national observed statistics of $€ 40$ per pig would have limited impact on gross margin volatility since pay-outs are limited. In case of a national-based coverage, annual pay-outs do not differ between farms. Given a threshold of $€ 60$ per pig, in $20 \%$ of the years all pig farmers receive a pay-out of at least $€ 11$ per pig (Table 3.3). 


\section{$4 \quad$ Conclusions and outlook}

Margin insurance is a relatively new concept of insurance covering the margin between revenues and cost of production. As the concept is potentially promising due to its joint consideration of revenues and costs it receives quite some interest in the policy domain. This report outlined the concept of margin insurance including its design and experiences in the US and EU, and assessed the impact of margin insurance for dairy and fattening pig farms in the Netherlands.

\subsection{Potential impact of gross margin insurance}

Fluctuations of input and output prices are major reasons behind volatile gross margins in livestock production. As illustrated in this report, there are large historic differences in the period 2001-2015 between the dairy sector and fattening pig sector in volatility. Relatively large fluctuations in gross margins were observed in the fattening pig sector (median CV value of $32 \%$ ). In the dairy sector gross margin between years was more smooth (median CV values of $12 \%$ ), but projections are that after the gradual reduction of EU milk price support and following the abolishment of the EU milk quota system, dairy farmers will become more exposed to the world market for dairy products and are becoming more vulnerable to (supply and demand) shocks affecting world dairy markets and prices.

The quantitative analyses within each sector revealed that there is substantial heterogeneity between farms in terms of gross margin and its volatility. Differences in gross margin stem not only from output prices received and input prices paid, but also from differences in the underlying technical results determining the efficiency of production (i.e., the amount of variable inputs required to produce output). Smaller farms are associated with statistically significant larger volatility in the case of the fattening pig sector, but farm size effect was absent in the dairy sector. In both sectors analysed there is no association between gross margin volatility and other parameters analysed (i.e., family farm income and financial leverage). This implies that gross margin insurance does not target specific groups of dairy farmers, while it targets more specifically smaller fattening pig farms.

Depending on coverage level, gross margin insurance could provide protection against the loss of gross margin. For example in the dairy sector, simulating a farm-specific coverage level threshold of $€ 0.25$ per kg milk would imply an average pay-out of approximately $€ 2,500$ per year per farm and would reduce volatility by $17 \%$ (of the median value). In the fattening sector, simulating for example a farm-specific coverage level threshold of $€ 50$ per pig would imply an average pay-out of approximately $€ 7,500$ per year per farm and would reduce volatility by $30 \%$ (of the median value). Furthermore, national-based triggers are less effective in smoothening gross margin, because of heterogeneous gross margins between farms.

Designing farm-specific gross margin insurance is data intensive as data are required on sales prices, input prices, and quantities (inputs, production). Moreover, moral hazard problems may occur as production volumes from intensive livestock systems are largely determined by farm management decisions and timing of sales is somewhat flexible. Using national-based data and triggers can circumvent data intensity and moral hazard issues but is found to be less effective.

With regard to the role of the public sector, two potential roles have been identified. Governments can financially intervene in gross margin insurance as a response to market failure with regard to covering correlated risks (e.g. prices and yields). Alternatively, they could provide incentives for price transparency, including collection and dissemination of information on price levels and price drivers, such as (local and international) storage levels. 


\subsection{Potential role of gross margin insurance}

With regard to the potential role of livestock gross margin insurance as a way to stabilise farm incomes within CAP various aspects need to be considered. These are summarised in Table 4.1, including a qualitative assessment of the aspects.

Table 4.1 Key issues on the feasibility of livestock margin insurance in the Netherlands a)

\begin{tabular}{lcc} 
& $\begin{array}{c}\text { Livestock margin insurance } \\
\text { covering market volatility } \\
\text { (margin between sales price and cost of } \\
\text { production) }\end{array}$ & $+/-$ \\
\hline Effectiveness (potential for risk reduction) & ++ & $+/-$ \\
\hline Efficiency (transaction costs) & + & $+/-$ \\
\hline Demand (farmer participation) & + & $+/-$ \\
\hline $\begin{array}{l}\text { Suppliers (insurance companies willing to engage in margin } \\
\text { insurance) }\end{array}$ & $+/-$ & + \\
\hline Data requirements & $+/-$ & + \\
\hline - Sales prices (observed) & $+/-$ & + \\
\hline - Input prices (observed) & $+/-$ & \\
\hline
\end{tabular}

a) Assessment ranging from -- (low) to ++ (high) potential.

\section{Effectiveness}

The effectiveness of a margin insurance is highest in case of farm-specific data (Chapter 3 ) and if both market and yield volatility are covered (score: ++ ). However, from a design perspective, covering yield risk for livestock commodities, especially for intensively kept livestock, is expected to be complex due to problems of asymmetric information (Chapter 2). Also for reasons of asymmetric information, the use of farm-specific data (yield and price) is expected to be problematic (Chapter 2). If indexbased parameters are used, the effectiveness is lower, as shown in Chapter 3 (score: +/-).

\section{Efficiency}

For livestock margin insurance covering the margin between sales and cost of production (such as in 'Model $A$ '), and assuming that price levels for both inputs and outputs are based on observed (e.g., national) data and cost of production is otherwise based on normative assumptions, transaction costs for the insurance are likely relatively low (score: +/-). If farm-specific data are to be used for premium rates and the triggering of pay-outs, instead of normative assumptions, demand will likely increase (score: + ), but transaction costs will substantially increase as more data are needed and underwriting as well as loss adjustment will be more intense in order to deal with adverse selection and moral hazard. However, in the future with digital access to invoice farm data these costs may come down substantially.

\section{Demand}

Demand for margin insurance is determined by various factors including coverage level, amount of basis risk and complexity of the programme. Depending on coverage level, gross margin insurance could provide in different degrees protection against the loss of gross margin (a 'buy-up' coverage implies more frequent and larger pay-outs compared to a catastrophic coverage, but would also imply higher risk premiums, see Chapters 2 and 3). Higher levels of demand would best be served if farmers could choose the coverage level themselves. Basis risk is expected to be higher when using nationalbased triggers compared to farm-specific triggers. Nevertheless, basis risk is expected to be relatively low for sales prices (e.g. use of price information of mainstream processors as FrieslandCampina price for milk and Vion price for pork, or aggregated national prices from www.agrimatie.nl). For inputs, prices of standard compound feed can be used (fattening pigs). For dairy, compound feed is a relatively small part of total feed used because of on-farm roughage production. For dairy farms this implies more basis risk. Also the use of normative values for amounts of inputs and production levels entails basis risk (score: +/-). With regard to the complexity of the product, the concept of margin 
insurance is expected to be perceived by farmers as less complex compared to for instance the use of futures markets or swap contracts (score: + ). Perceived complexity will also be reduced by transparency on the establishment of price levels and normative values.

\section{Suppliers}

For commercial insurers to engage in livestock margin insurance programmes the availability of observed price data will be an important factor, as well as the potential for a public-private partnership, e.g. with regard to reinsurance. Although for the latter experience exists with regard to among others extreme weather insurance and the Dutch animal health fund in the Netherlands, no examples exist yet with regard to public-private partnerships for margin insurance programmes in Europe (score: +/-). In the past, the Dutch government provided a non-proportional reinsurance cover for several weather events, but these schemes evolved into multi-peril crop insurance schemes with premium subsidy. However, a non-proportional cost sharing system has been running since 1998 to publicly reinsure losses in the event of outbreaks of contagious livestock diseases. A similar approach is unlikely for margin insurance because significant amounts of public funds need to be blocked to reinsure market risks, with uncertainty on their use. In the absence of a public re-insurance the insurers needs to hedge their risks by means of using futures or initiate forward sales price contracts with downstream processors or input prices with upstream suppliers. However, these contracts have hardly been established in the Netherlands.

\section{Data}

If observed (national-based) data are used for prices (e.g. monthly levels of milk, pork and feed prices), data availability does not seem to be problematic (although exact weighing of underlying components must be agreed upon). Input and output prices (i.e., milk, meat and compound feed) reported by the dominant actors in the value chain are publically available. Likewise, data are available to establish normative averages (score: + ). However, for farm-specific insurance, availability of data seems more problematic. Usefulness of remote sensing to monitor e.g. yield levels and management practices is still under research (score: $+/-$ ).

\subsection{Outlook gross margin insurance and CAP}

Opportunities exist in designing and pricing an efficient and effective margin insurance. But difficulties do arise both at the demand side and supply side. It is therefore not likely that a private market will develop soon.

In a commercial market, design and price of risk management instruments can be expected to be actuarially sound. Introducing subsidies, either for farmers to lower their premium pay-outs or for private companies to reduce their transaction and reinsurance costs, is likely to bring distortions to the system (e.g., resource misallocation, rent seeking, capitalisation, moral hazard and crowding out). If margin insurance is based on observed data, distortions are less than for programmes based on farmspecific data. For instance, the dairy margin protection programme is described as partly decoupled, because pay-outs are not triggered by a farmer's production level, but they are impacted by current market conditions (i.e. milk and feed prices).

Besides subsidies, other areas for policy support include the further encouragement of cooperation among farmers and along the chain, the establishment of futures markets where such markets are missing, and the timely dissemination of improved and accessible market price data and predictions. Such price data could be used to support chain actors' production and sales decisions, as well as pricing and contract decisions. 


\section{References and websites}

Assefa, T.T., M.P.M. Meuwissen and A.G.J.M. Oude Lansink (2016). Price volatility perceptions, management strategies, and policy options in EU food supply chains. In: Garrido, A., Brümmer, B., M'Barek, R., Meuwissen, M.P.M., and Morales-Opazo, C. (eds), Agricultural Markets Instability; revisiting the recent food crises, Routledge, New York, pp. 178-192.

Bozic, M., C. Wolf, F. Yang, J. Newton and C.S. Thraen (2014). Margin Protection Program for Dairy Producers: Implementation, Participation and Consequences. Paper presented at the Agricultural \& Applied Economics Association Crop Insurance and the 2014 Farm Bill Symposium, Louisville, KY, October 8-9, 2014.

DLV (2015). Eindbrochure Demonstratieproject Afdeling Duurzame Landbouwontwikkeling, Bevordering van de rentabiliteit in de varkenssector door verstrekken van marktinformatie en door afdekken van voedermarges (via termijnmarkt en fysieke contractwerking).

Dolman, M.A., H.C.J. Vrolijk and I.J.M. de Boer (2012). Exploring variation in economic, environmental and societal performance among Dutch fattening pig farms. Livestock Science, 149(1-2), 143154.

Diederen, P., H. van Meijl, A. Wolters and K. Bijak (2003). 'Innovation adoption in agriculture : innovators, early adopters and laggards.' Cahiers d'Economie et de Sociologie Rurales (CESR) 67.

European Commission (2016). Call for tenders. N AGRI-2016-EVAL-07. Study on risk management in EU agriculture, Brussels.

European Parliament (2015A). Terms of reference for a research study on state of play of risk management tools implemented by member states during the period 2014-2020: national and comparative frameworks. IP/B/AGRI/IC/2015-075, Brussels.

European Parliament (2015B). Research for Agri Committee - State of play of risk management tools implemented by member states during the period 2014-2020: national and comparative frameworks. IP/B/AGRI/IC/2015-075, Brussels.

Galtier, F. et al. (2012). 'Gérer l'instabilité des prix alimentaires dans les pays en développement Une analyse critique des stratégies et des instruments'. Agence Française de Développement, Décembre 2012.

Goodwin, B.K. and A. Hungerford (2014). Copula-based models of systemic risk in U.S. agriculture: I mplications for crop insurance and reinsurance contracts. American Journal of Agricultural Economics, 97(3), 879-896.

Jongeneel, R. and S. van Berkum (2015). What will happen after the EU milk quota system expires in 2015? An assessment of the Dutch dairy sector. Wageningen, LEI Wageningen UR (University \& Research centre), LEI Report 2015-041.

Lans, T., M.A. van Galen, J.A.A.M. Verstegen, H.J.A. Biemans and M. Mulder (2014). 'Searching for entrepreneurs among small business ownermanagers in agriculture.' NJ AS - Wageningen Journal of Life Sciences 68: 41-51.'

MacDonald, M., J. Cessna and R. Mosheim (2016). Changing Structure, Financial Risks, and Government Policy for the U.S. Dairy Industry, ERR-205, U.S. Department of Agriculture, Economic Research Service, Washington DC.

Mark, T.B., K.H. Burdine, J. Cessna and E. Dohlman (2016). The Effects of the Margin Protection Program for Dairy Producers. USDA, Economic Research Service, report no 214, Washington DC.

Matthews, A. (2016). The future of direct pay-outs. In: Research for Agri-Committee CAP reform post 2020 challenges for agriculture. European Parliament, Brussels, pp 3-86.

Meuwissen, M.P.M., T. Assefa and M.A.P.M. van Asseldonk (2013). Supporting insurance in European agriculture; experience of mutuals in the Netherlands. EuroChoices 12(3), 10-16.

United states department of Agriculture (2010). Livestock Gross Margin for Cattle Insurance Policy. http: //www.rma.usda.gov/policies/2010/lgm/10lgmcattlepolicy.pdf, Acessed 23-06-2016.

United states department of Agriculture (2014). A Risk Management Agency Fact Sheet, Livestock gross margin Swine. http://www.rma.usda.gov/pubs/rme/lgmswine. pdf, Acessed 23-06-2016.

United states department of Agriculture, 2012. Livestock Gross Margin for Swine Insurance Policy. http://www.rma.usda.gov/policies/2012/lgm/12-lgm-swine-policy.pdf, Acessed 23-06-2016. 
United states department of Agriculture, 2015. A Risk Management Agency Fact Sheet, Margin protection for federal crop insurance, http://www.rma.usda.gov/pubs/rme/mp.pdf, acessed 23-06-2016.

USDA (2016). Fact sheet Margin Protection Program for dairy (MPP-dairy). USDA, Washington DC.

Van Asseldonk, M. and R. van der Meer (2016). Coping with price risks on Dutch farms. Report LEI 2016-054, The Hague.

Vrolijk, H., and Poppe, K., (2008). Income volatility and income crises in the European Union. In: Meuwissen, M., Van Asseldonk, M. and Huirne, H., Income stabilisation in European agriculture: Design and economic impact of risk management tools. Wageningen Academic publishers, Wageningen.

Vrolijk, H.C.J., C.J .A.M. de Bont, H.B. van der Veen, J.H. Wisman and K.J. Poppe (2009). Volatility of farm incomes, prices and yields in the European Union. Report 2009-005, LEI Wageningen UR, The Hague.

Vrolijk, H.C.J., Van der Veen, H.B.,Van Dijk, J.P.M. (2010). Sample of Dutch FADN 2008; Design principles and quality of the sample of agricultural and horticultural holdings. LEI Wageningen UR, The Hague. 


\section{Appendix 1 Family farm income volatility}
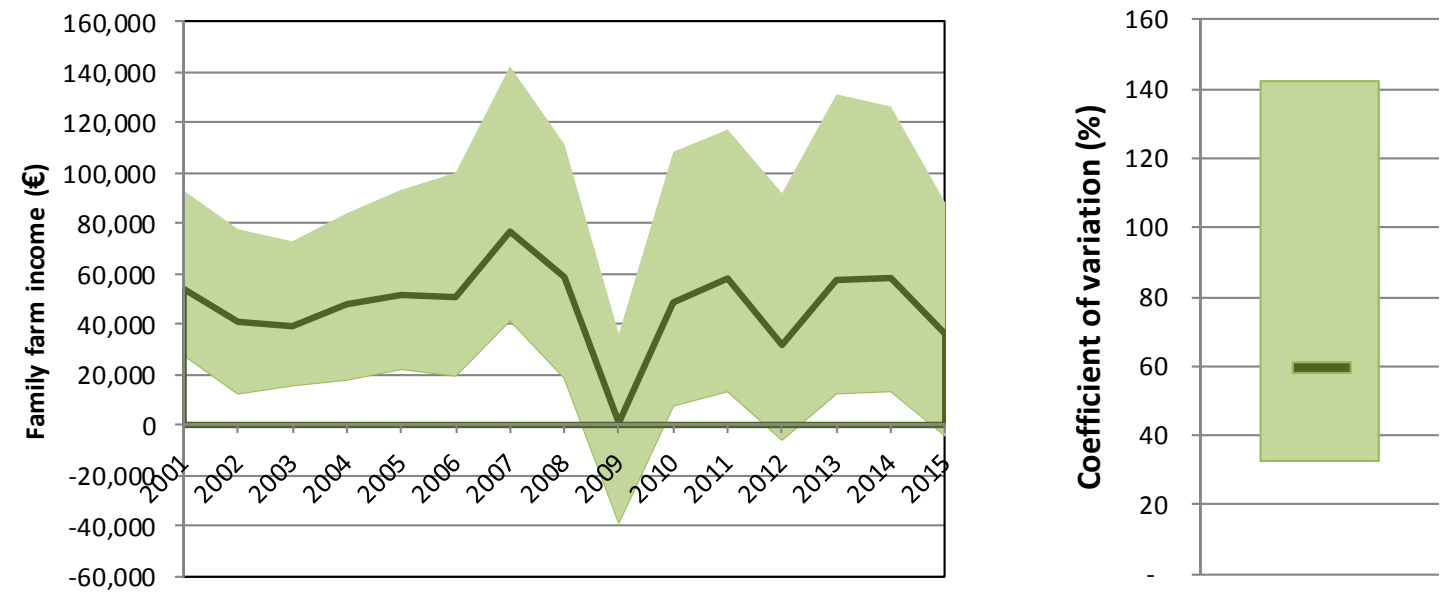

Figure A1.1 Volatility family farm income and coefficient of variation on dairy farms (median, P20 and P50)
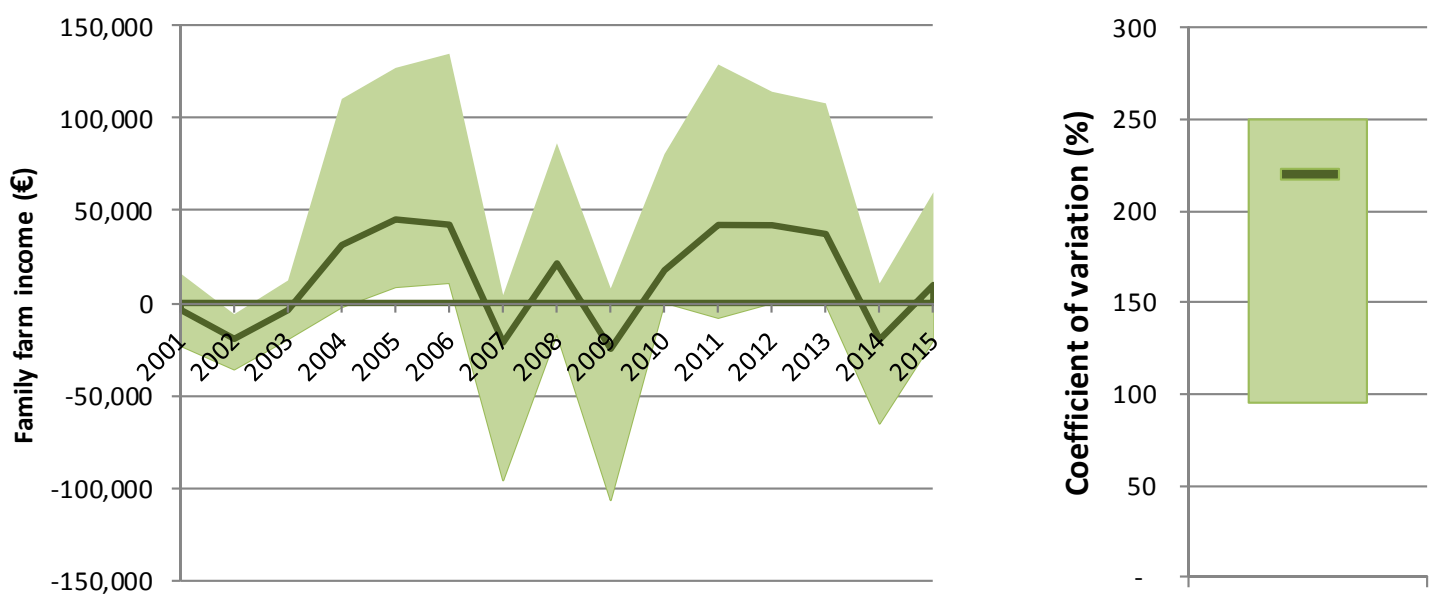

Figure A1.2 Volatility family farm income and coefficient of variation on pig farms (median, P20 and P50) 
Wageningen Economic Research P.O. Box 29703

2502 LS The Hague

The Netherlands

T +31 (0)70 3358330

E communications.ssg@wur.nl

www.wur.eu/economic-research

Wageningen Economic Research REPORT

2017-026
The mission of Wageningen University and Research is "To explore the potential of nature to improve the quality of life". Under the banner Wageningen University \& Research, Wageningen University and the specialised research institutes of the Wageningen Research Foundation have joined forces in contributing to finding solutions to important questions in the domain of healthy food and living environment. With its roughly 30 branches, 5,000 employees and 10,000 students, Wageningen University \& Research is one of the leading organisations in its domain. The unique Wageningen approach lies in its integrated approach to issues and the collaboration between different disciplines.

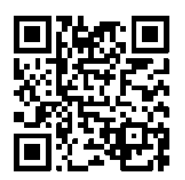





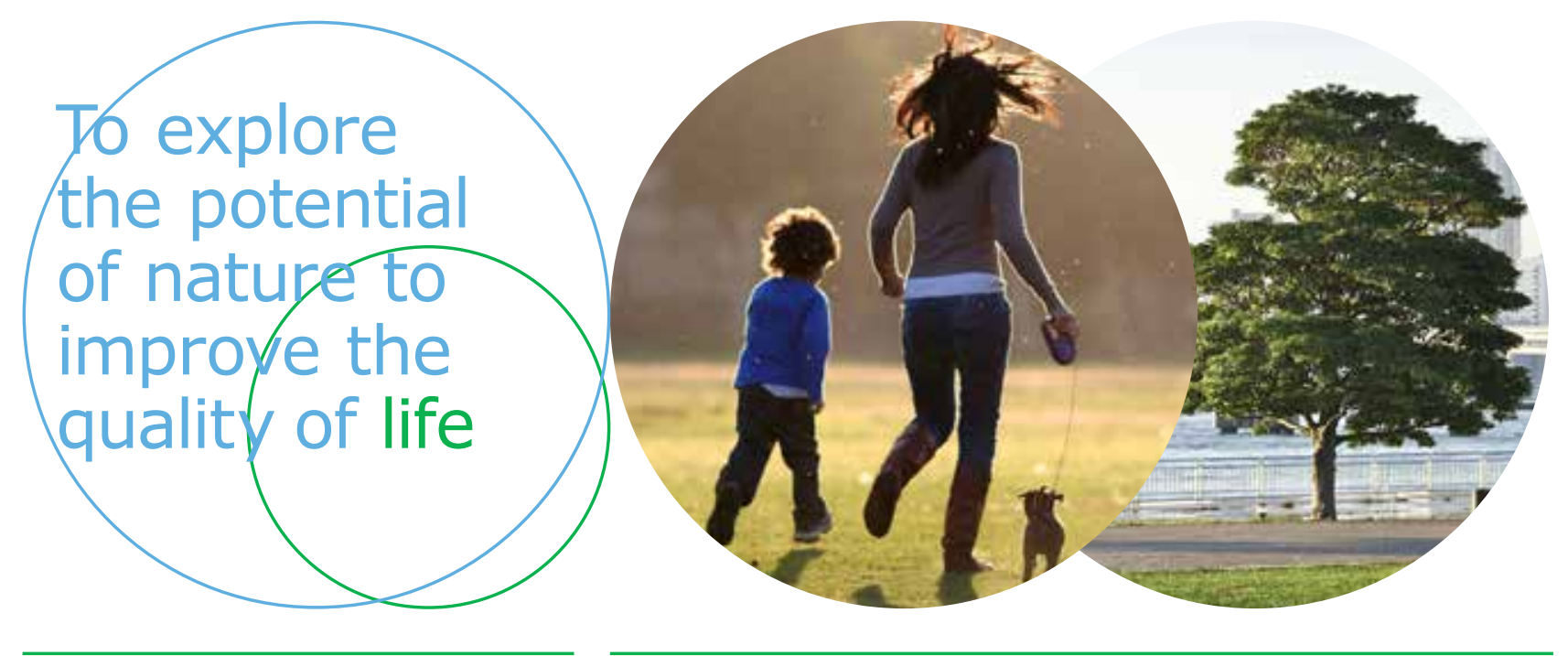

Wageningen Economic Research P.O. Box 29703

2502 LS Den Haag

The Netherlands

E communications.ssg@wur.nl

www.wur.eu/economic-research

Report 2017-026

ISBN 978-94-6343-461-4
The mission of Wageningen University and Research is "To explore the potential of nature to improve the quality of life". Under the banner Wageningen University \& Research, Wageningen University and the specialised research institutes of the Wageningen Research Foundation have joined forces in contributing to finding solutions to important questions in the domain of healthy food and living environment. With its roughly 30 branches, 5,000 employees and 10,000 students, Wageningen University \& Research is one of the leading organisations in its domain. The unique Wageningen approach lies in its integrated approach to issues and the collaboration between different disciplines. 